NBER WORKING PAPER SERIES

\title{
DO FEDERAL PROGRAMS AFFECT INTERNAL MIGRATION? THE IMPACT OF NEW DEAL EXPENDITURES ON MOBILITY DURING THE GREAT DEPRESSION
}

\author{
Price V. Fishback \\ William C. Horrace \\ Shawn Kantor \\ Working Paper 8283 \\ http://www.nber.org/papers/w8283 \\ NATIONAL BUREAU OF ECONOMIC RESEARCH \\ 1050 Massachusetts Avenue \\ Cambridge, MA 02138 \\ May 2001
}

The authors are deeply indebted to Larry Neal and Joseph Mason who facilitated the collection of the New Deal data used in the paper. We thank seminar participants at the 2000 NBER Summer Institute for valuable advice. The paper benefited from specific suggestions by Lee Alston, Joseph Ferrie, Larry Katz, Gary Libecap, Robert Margo, Kenneth Sokoloff, and John Wallis. Kari Beardsley, Amanda Ebel, Michael Hunter, Angela Phillips, Ruthanna Ruffer, and Jeffrey Taylor did excellent work in computerizing the data. Financial support has been provided by National Science Foundation Grants SBR-9708098 and SES-0080324, the Earhart Foundation, the University of Arizona Foundation, and the University of Arizona Office of the Vice President for Research. The views expressed herein are those of the authors and not necessarily those of the National Bureau of Economic Research.

(C) 2001 by Price V. Fishback, William C. Horrace and Shawn Kantor. All rights reserved. Short sections of text, not to exceed two paragraphs, may be quoted without explicit permission provided that full credit, including $\odot$ notice, is given to the source. 
Do Federal Programs Affect Internal Migration? The Impact of New Deal

Expenditures on Mobility During the Great Depression

Price V. Fishback, William C. Horrace and Shawn Kantor

NBER Working Paper No. 8283

May 2001

JEL No. H53, I38, J68, N32, O15, R23

\begin{abstract}
$\underline{\text { ABSTRACT }}$
Using a recently-uncovered data set that describes over 30 federal New Deal spending, loan, and mortgage insurance programs across all U.S. counties from 1933 to 1939, this paper empirically examines the New Deal's impact on inter-county migration from 1930 to 1940 . We construct a net migration measure for each county as the difference between the Census's reported population change from 1930 to 1940 and the natural increase in population (births minus infant deaths minus non-infant deaths) over the same period. Our empirical approach accounts for both the simultaneity between New Deal allocations and migration and the geographic spillovers that likely resulted when spending in one county may have affected the migration decisions of people in neighboring counties. We find that greater spending on relief and public works and a larger value of loans insured by the Federal Housing Administration were all associated with migration into counties where such money was allocated. The FHA's stimulus to the housing industry and large-scale public works projects explain most of the regional variation in migration rates across the country. New Deal loans and agricultural spending to take land out of production had negligible effects on migration patterns.
\end{abstract}

Price V. Fishback

Department of Economics

McClelland Hall 401

University of Arizona

Tucson, AZ 85721

and NBER

(520) 621-4421

pfishback@bpa.arizona.edu
William C. Horrace

Department of Economics

McClelland Hall 401

University of Arizona

Tucson, AZ 85721

and NBER

(520) 621-6230

whorrace@u.arizona.edu
Shawn Kantor

Department of Economics McClelland Hall 401

University of Arizona

Tucson, AZ 85721

and NBER

(520) 621-6226

skantor@u.arizona.edu 


\section{Introduction}

Migration has long been a central issue in understanding economic development. ${ }^{1}$ A citizen's ability to move also has important political-economy ramifications. State and local governments must set fiscal and social policies subject to the constraint that citizens can exit and/or enter. Many modern studies that attempt to determine how various public policies affect migration incentives often focus on moves across state lines either due to data limitations or because the federal government's increasingly strong role in social policy over the course of the twentieth century has served to reduce the variation in benefits across local jurisdictions. Yet more people migrate across counties within states than migrate across state lines (U.S. Bureau of the Census 1975, 76). Thus many "welfare magnet" migration studies miss a significant portion of the migration activity across political boundaries. ${ }^{2}$ These intrastate political boundaries were particularly important in earlier historical periods when social welfare policies were set more by local jurisdictions than they are today and especially during the 1930s when the federal government distributed dramatically different amounts of money per capita across states and across counties within states.

To better understand how social programs might affect migration decisions, this paper explores a unique episode in American history. During the Great Depression there were substantial variations in the economic downturn across the country, which led to examples like the Joad family's escape from the Oklahoma dust bowl so vividly portrayed by John Steinbeck in The Grapes of Wrath. What made the 1930s unique was the federal government's unprecedented large-scale entry into the provision of direct relief, work relief, public works projects, and farm subsidy programs. The amounts spent staggered the imagination at the time. More importantly for the purposes of our investigation, the amounts spent varied substantially across states and often were even more variable from county to county within states.

Further, the relief and public works programs are predicted to have different effects on net migration than the farm programs. Unlike many studies that focus on only one type of program, we examine both types of program simultaneously. The migrations in response to these differences in federal spending on the 
various programs had the potential to lead to a substantial realignment of the American population. Internal migration during the 1930 s was generally smaller than in the surrounding decades, as has been the case in most modern recessions. ${ }^{3}$ Even so, there were still substantial flows of migrants. In 1940 approximately 11 percent of the population had migrated since 1935 and 60 percent of them had moved within the same state (U.S. Bureau of the Census 1943, 5).

After entering office in 1933, the Roosevelt administration introduced a number of emergency spending programs, while also establishing many of the federal social policies that exist today, such as unemployment insurance, social security, and the minimum wage. During the course of the 1930s the amounts that all governments paid out for public aid in the form of work relief, public works spending, direct relief, and the social security aid programs rose 10 to 20 fold. The U.S. moved away from a purely state and local system of public aid prior to 1933 to a situation where the federal government spent nearly 5 times as much on public aid as the states did during the middle 1930s. By the end of the 1930s the federal government was still spending nearly 2.5 times as much as state and local governments on public assistance. Much of the federal public assistance came in the form of work relief that contributed to the building of civil infrastructure. Large numbers of the unemployed also found work on federal public works projects that built federal roads, dams, buildings, and other projects in unprecedented numbers. The Agricultural Adjustment Administration first introduced payments to farmers to take land out of production, which led to fundamental changes in the demand for farm labor and potentially a redistribution of income from farm workers to landowners. Had the various New Deal programs been evenly distributed across the country, these programs probably would have had only a limited effect on net migration. On a per capita basis, however, New Deal spending during the 1930s was highly variable from county to county. With such variation the New Deal programs might well have influenced people's decisions to move during the heart of the Great Depression. ${ }^{4}$

Using census data on the change in population between 1930 and 1940 and county-level counts of births and deaths throughout the 1930s, we have developed new estimates of net migration for over 3,000 counties during the 1930s using the U.S. Bureau of the Census components-of-change method. ${ }^{5}$ The data 
allow consideration of the significant amount of intrastate migration that is overlooked in many migration studies. After comparing and contrasting our estimates of net migration with earlier estimates by Gardner and Cohen (1992), we combine the net migration data with our New Deal information to examine how migration patterns during the 1930 s were influenced by the federal government's intervention in the depressed economy. We use ordinary least squares estimates to establish the baseline relationship between net migration and New Deal grants, economic activity, and a variety of social, demographic, and geographic factors. We then move to a two stage least squares (2SLS) instrumental variables approach to control for the potential endogeneity of New Deal spending. Finally, we examine the impact of spatial correlations in the errors and geographic spillover effects of economic activity using a generalized two stage least squares technique developed by Kelejian and Prucha (1998). Controlling for the spatial correlation in a migration study is important because people moving into one county necessarily came from another county, creating a spatial dependence across counties.

The results suggest that New Deal spending had quite varied effects on net migration. Federal spending on public works and relief programs contributed to significant net in-migration, accounting for between 5 and 16 percent of the difference in average net migration rates between counties with net inmigration and counties with net out-migration. Meanwhile, the introduction of our modern farm programs under the aegis of the Agricultural Adjustment Administration appears to have contributed to a net out-migration that sped the transition of people out of farming. Differences in average AAA spending explain between 3 to 5 percent of the difference in net out-migration rates between the two types of counties. Finally, differences in economic activity across counties, measured by retail sales per capita, explain 10 percent and possibly more of the differences in net migration rates for the two types of counties.

\section{New Estimates of Net Migration Between 1930 and 1940}

We have developed new estimates of net migration for each county during the 1930s. Annual data on births, deaths, infant deaths, and stillbirths in each county during the 1930s were collected from 
the U.S. Census's vital statistics reports. These demographic data allow us to calculate net migration into or out of each county from 1930 to 1940 as a residual measure, also known as the components-of-change method. The measure is defined as the difference between the Census's reported population change from 1930 to 1940 and the natural increase in population (births minus infant deaths minus non-infant deaths) over the same period, 1930 through 1940. Therefore,

$$
\begin{aligned}
\text { Net Migration }= & \text { Population }(1940)-\text { Population }(1930)- \\
& \Sigma_{1930 \text { to } 1940}(\text { Births }- \text { Adult Deaths }- \text { Infant Deaths })
\end{aligned}
$$

We then adjusted the measure to account for the undercounting of births in each state (see Data Appendix I). A net migration rate per 1,000 is then calculated using the 1930 population. Throughout the paper we focus the discussion on internal migration within the United States, but county-level net migration estimates can also be affected by international migration. Because annual immigration into the United States slowed to among the lowest levels in American history by the combination of the Depression and restrictions on immigration, international movements were probably only a small part of the net migration equation in an individual county.

Our estimates of county-level net-migration offer an alternative to those that Gardner and Cohen (henceforth, GC) developed. GC also used a residual technique based on the difference in population between 1930 and 1940 and an estimate of the natural rate of increase. Their estimates of the natural rate of increase, however, were developed by applying national survival rates from 1930 to 1940 for each age/sex/race group in the U.S. to the age/sex/race structure in each county in 1930. Since the survival method provides little guidance for the 0-9 age group, their estimate of net migration is for people over the age of nine as of 1940, which implies that birth rates are irrelevant to their migration calculations. ${ }^{7}$

GC's method of estimating the natural rate of increase is subject to measurement error because it applies national survival rates to a diverse set of counties. Our measure also could suffer from measurement error to the extent that births and deaths were inaccurately reported. Such measurement error may not have been fully eliminated even after adjusting for state-level birth undercounts. We believe that our measure of net migration is better suited for analyzing the impact of the New Deal 
because once we include controls for the age, sex, and racial composition of the county population in 1930, we have controlled nearly all of the cross-sectional variation that GC use to develop their residual net migration estimates. Thus, nearly all of the cross-sectional variation that is left is driven purely by the difference in population between 1930 and 1940. In essence, the controls for age, sex, and race would turn a regression analysis using the GC measure into an examination of population growth.

We have performed extensive comparisons of the two measures, which are reported in an Appendix available from the authors. Despite the differences in the techniques, it is reassuring that our estimate and the GC estimate are closely related, displaying a correlation across counties of .98. There is no direct measure of net migration for the entire decade at any level, but the 1940 Census contained a question about migration between 1935 and 1940 that can be used to determine net migration for that period for some geographic levels. The Census did not report information at the county level, but we can make comparisons at the state level. The correlation between our 1930-1940 estimates aggregated to the state level and the state-level Census 1935-1940 measure is .94. The GC estimates, aggregated to the state level, have a correlation of .92 with the 1940 Census measure. ${ }^{8}$ Table 1 shows a comparison of the net migration rates using all three methodologies at the state level. The three measures similarly suggest that the states with the highest rates of net in-migration include Florida, California, Nevada, Oregon, Delaware, Maryland, New Mexico, Washington, and Idaho. The largest out-migration rates were found in the Great Plains states of North Dakota, South Dakota, Oklahoma, Kansas and Nebraska and the southern states of Arkansas, Alabama, Mississippi, and Georgia. There was also substantial variation within states, as the standard deviation of our net migration rate within 26 states was larger than the standard deviation across the country for the state averages. As a check on the robustness of our empirical analysis of the determinants of migration, we estimated the models below using both our measure and the GC measure. Since the results are very similar under both sets of estimates, we focus the discussion in the paper on our estimated migration rates. ${ }^{9}$

\section{New Deal Grants}


The myriad of economic problems arising from the Great Depression led the Roosevelt administration to develop a variety of New Deal programs, ranging from the building of infrastructure to the regulation of employment, industry, and the financial sector. Our specific focus is on the New Deal programs that distributed federal money in the form of non-repayable grants. In 1940 the U.S. Office of Government Reports (OGR) compiled a detailed statistical description of the federal government's grant expenditures in over 3,000 counties for the period March 3, 1933, through July 30, 1939. ${ }^{10}$ Most prior research based on the OGR data has made use of the state-level reports. Only recently have scholars begun to use the county-level information. ${ }^{11}$

The federal government distributed $\$ 16.5$ billion in non-repayable grants over the six-year period. The grants represented an unprecedented role for the federal government during peacetime. The New Deal increased the federal government's outlays as a share of GDP from about 4 to 8 percent. Furthermore, the federal government began spending large amounts of money where it had spent very little before, setting the stage for a long-term structural shift in the financial responsibilities of the national, state, and local governments. ${ }^{12}$ As a share of government expenditures at all levels, the New Deal raised the proportion of federal spending from 30 percent in 1932 to 46 percent by 1940 (Wallis $1984,141-42)$.

We can divide the non-repayable New Deal grants into two major categories that potentially had quite different impacts on the economy - public works and relief grants; and Agricultural Adjustment Administration (AAA) benefits paid to farmers. We group public works and relief grants together because the programs had broadly similar goals of providing employment for a large number of workers and building a wide variety of public works and providing other public services. Relief grants were primarily distributed under the auspices of the Federal Emergency Relief Administration (FERA) from 1933 through mid 1935, the Civil Works Administration (CWA) from November 1933 through March 1934, the Works Progress Administration (WPA) from mid 1935 through 1942, and the Social Security Administration's Aid to the Blind, Aid to Dependent Children, and Old-Age Assistance programs after 1935. The principal goal of these programs was to provide immediate relief to the unemployed and low- 
income people, as 85 percent of the grants were used to hire the unemployed on work relief jobs. These relief jobs ranged from make-work activities to maintenance activities to the building of sidewalks, post offices, schools, local roads, and other additions to local infrastructure. The public works grants included expenditures by the Public Works Administration (PWA), Public Buildings Administration, and the Public Roads Administration. These grants were also used largely to employ workers. Many of the workers hired came from the relief rolls, but the public works programs had more freedom to hire a broader class of workers who were not on relief. The public works programs were said to be more focused on building larger scale projects such as dams, roads, schools, and sanitation facilities. The work relief programs also built many major public projects, as relief administrators typically carved large-scale projects into several small projects that allowed them to avoid administrative limits (Clarke 1996, 62-68; Schlesinger 1958, 263-96).

The major relief and public works programs had the potential to stimulate migration across counties, as the unemployed sought work in areas with new relief and public works projects. The economics literature on the impact of welfare benefits on locational choice in the modern era is mixed, some find that movement of low-income people is positively correlated to differences in states' welfare benefit levels (Gramlich and Laren 1984, Blank 1988, Moffit 1992), while others find a small or negligible effect (Allard and Danziger 2000; Kauffman and Kiesling 1999, and Levine and Zimmerman 1999). We should note that our measure of relief and public works spending is total spending per capita, so it combines both differences in the number of people obtaining funds and the monthly payments to recipients of emergency jobs or direct relief. There were federal efforts to establish a certain minimum level of benefits, but the eventual compromise between officials at all levels was to pay attention to prevailing wage levels. Faced with extraordinary unemployment rates, relief officials were forced to make tradeoffs between providing adequate benefits and finding work for as many unemployed workers as possible (see Brown 1940, Howard 1943, Williams 1968, Wallis and Benjamin 1981). Given the large number of unemployed workers, access to benefits might have been as important as the actual level of benefits. 
Since the public works and relief projects involved not only relief of economic distress, but also led to expansions in civil infrastructure that potentially promoted economic activity in a deeply depressed national economy, we might expect to see more of a migration response in the 1930s than we would for federal welfare programs in the modern era. The migration response during the Depression, however, might have been limited by a complex web of residency requirements for relief eligibility. Unlike modern federal welfare programs that have largely eliminated residency requirements since 1970 (Gramlich and Laren 1984, 490), the residency requirements of the Depression-era relief programs were quite complex and may have mitigated the incentive to migrate simply because grant expenditures were more generous elsewhere. Donald Howard (1943, 332-7) noted that the official WPA policy as of 1939 was that eligible people could not be refused certification for work relief jobs on the basis of nonresidence in the area. At the same time, the WPA did not want families moving for the "sole purpose" of obtaining a relief job. Most of the barriers to movement were erected by state and local bureaucracies, which created elaborate procedures for transferring workers' records from one state to another and required that workers reestablish their eligibility in new places, among other factors. An unemployed worker took an additional risk by moving because state and local length-of-residency requirements for direct relief and public assistance may have differed. The de facto result might have been limits on nonresidents' abilities to qualify for the WPA positions. On the other hand, to the extent that work relief projects stimulated the local economy, there may have been increased private opportunities for migrants.

The FERA policies for most types of relief were similar to the later WPA policies, although the FERA explicitly provided a small portion of its funds for the transient population. Josephine Brown (1940, 250) noted that federal FERA policy forbade discrimination against non-residents, blacks, aliens, and veterans, "yet the fact remained that the actual administration of relief was in the hands of local authorities and the promulgation of a rule by the FERA was not sufficient in many cases to overcome sectional traditions and prejudices in a comparatively short time." Aware of this problem, the FERA formulated a transient program for workers with less than a year's continuous residence (Williams 1968, 172-3). The program was funded by the federal government and administered by the states. It typically 
provided aid to the transient unemployed who could not have obtained aid under the legal settlement or residency requirements of the states (Webb 1936, 1-4, 16). The transient program accounted for about 2 percent of the total obligations of FERA programs (Federal Works Agency, Works Progress Administration 1942, 74 and 81), so in the final analysis the impact of FERA spending on migration patterns may not have differed much from that of the WPA. ${ }^{13}$

The public works programs under the Public Works Administration, Public Buildings Administration, and the Public Roads Administration also were influenced by residency requirements because they too hired from the relief rolls. However, the mandates for these agencies allowed them to focus less on providing immediate employment and more on building long-term, large-scale projects like dams, roads, schools, sanitation facilities, and other forms of civil infrastructure. Thus, administrators followed longer lead times in developing projects, had more leeway in using funds for materials, and worried more about hiring workers with the specific skills needed to complete a particular project (Schlesinger 1958, 263-96; Clarke 1996, 62-68). As a result, they operated with fewer restrictions on hiring from the resident labor pool near the project because a number of the projects were in relatively isolated areas.

The other major category of New Deal grant funding was the AAA's payments to farmers to remove land from production. The impact of the Agricultural Adjustment Act on net migration combines countervailing effects for different groups in the farm economy. A simple analysis might suggest that AAA spending, by putting more money directly into the hands of farmers, stimulated economic activity. At the margin, for farm owners who were on the verge of shutting down and leaving farming, the AAA payments likely kept them from leaving. On the other hand, a number of scholars suggest that the consequences of AAA spending might have led to the out-migration of farm workers and tenants. The AAA spending on rental and benefit payments through 1935 and on conservation payments after 1936 were designed to reduce acreage under production. The reduction of acreage likely caused a direct decline in the demand for the labor services of sharecroppers, cash renters, and wage laborers. Lee Alston (1981) argues that the AAA encouraged landowners to mechanize, which lowered the demand even 
further. Other scholars suggest that landowners received the bulk of AAA payments, while tenants and sharecroppers often did not receive shares commensurate with their productive activity. A number of tenants and croppers, as a result, may have lost their positions (see Holley, Winston, and Woofter 1971; Saloutos 1974; Mertz 1978; Whatley 1983; Biles 1994, 39-43). All of these changes suggest that areas with larger per capita AAA payments were likely to experience net out-migration among farm workers. Thus, when measuring the final effect of the AAA payments on net migration in a cross-section of counties, the result will depend on whether the outflow of farm laborers was more than offset by a reduction in the exodus of farm owners.

Table 1 shows the variation in public works and relief spending and in AAA spending across states. The variation across counties within states was often greater than the variation across states. Table 2 in Fishback, Horrace, and Kantor's (forthcoming March 2005) study of the variation in retail sales per capita shows the means, standard deviations, and minimums and maximums for each county. The literature on the determinants of the distribution of New Deal funds has focused on whether the Roosevelt administration used the funds to promote relief, reform, and recovery or to promote their own presidential aspirations. An extensive discussion of these issues for nearly 20 New Deal programs and citations to the substantial literature on the topic at the state level is available in Fishback, Kantor, and Wallis (2003). The impact of nearly all of the variables found in those studies on New Deal spending can be seen in the first-stage equations in the far right of Table 3 below.

\section{An Empirical Model of Migration and the New Deal}

Given the disparate impact of the depression across the country and the unequal distribution of New Deal spending, we would expect that people moved if they were able to enhance their economic positions (Greenwood 1975 and 1985). The net migration rate that we are modeling is the difference between in-migration and out-migration at the county level. Studies of migration suggest that economic opportunities, the demographics of the population, public policies, and county amenities and disamenities generally influence net migration. The following equation can be used to conceptualize the analysis:

$$
M_{i}=a_{0}+a_{1} Y_{i}+a_{2} R_{i}+a_{3} A_{i}+a_{4} \Delta P_{20-30 i}+\sum_{k} a_{k} D_{i}^{k}+\Sigma_{n} a_{n} E_{i}^{n}+a_{s} S+\varepsilon_{i}
$$


$\mathrm{M}_{\mathrm{i}}$ is the average annual net migration during the 1930s in county i (measured as a rate per thousand people in 1930). $Y_{i}$ is a measure of average annual income per capita, $R_{i}$ is average annual per capita New Deal relief and public works spending, and $\mathrm{A}_{\mathrm{i}}$ is average annual per capita AAA spending in county i. Because migration patterns of the 1930s may have been based on prior trends, which could have influenced New Deal spending, we have included a proxy for net migration during the 1920s - the growth rate in population from 1920 to $1930\left(\Delta \mathrm{P}_{20-30}\right) .{ }^{14}$ By controlling for prior population growth, we have attempted to capture the impact of path dependence and prior migration trends. Numerous studies show that there is substantial heterogeneity in the propensity to move among people of various demographic backgrounds. The sum $\Sigma_{\mathrm{k}} \mathrm{a}_{\mathrm{k}} \mathrm{D}_{\mathrm{i}}^{\mathrm{k}}$ indicates a series of coefficients and variables that describe the various demographic features of the population in 1930, including the percentages of the population that lived in urban areas and that were black, foreign born, and in various age groups. The environmental or geographic amenities and disamenities associated with living in county i were also likely to influence migration decisions and these factors are included in the $\Sigma_{n} a_{n} E_{i}^{n}$ term. To help further reduce unmeasured heterogeneity across counties, we have included a vector of state dummy variables, S, to control for differences in state spending on various New Deal programs, taxation, cost-of-living, amenities, and other factors that were common to all counties within the same state, but varied across states. $\varepsilon_{\mathrm{i}}$ is the error term.

A potential problem that arises in estimating the impact of various variables on net migration is that the demographic or economic correlates may themselves have been influenced by migration during the 1930s. For example, the age distribution in an area where there was substantial net in-migration was likely to become more skewed toward young adult ages because they were more likely to migrate. Thus, coefficients using variables measured during the 1930 s or 1940 will display some simultaneity bias. To reduce this form of bias, at every opportunity we have used information on the economic or demographic environment in a county in 1929 and 1930. As a result, for all but the climate and geography variables which were unaffected by migration decisions - and the New Deal variables, the analysis examines the 
relationship between net migration during the 1930s and the economic and demographic structure of the counties just prior to the period when the net migration began.

Because comprehensive income estimates are not available at the county level, we use retail sales per capita in 1929 as a proxy for personal income. ${ }^{15}$ We chose retail sales because it was available for every county, unlike measures of manufacturing earnings per worker and several other measures. More importantly, retail sales seem to be highly correlated with personal income. Correlations of state-level per capita personal income and retail sales for the years 1929, 1933, 1935, and 1939 are $.87, .89, .88$, and .90, respectively. In addition to retail sales per capita, we have also included information on the percentage of the population aged 10 and over that was unemployed or laid off in 1930, the percentage of families owning their own home in 1930, the percentage of farms operated by owners in 1929, and the percentage of cultivated acreage that with crop failures in $1929 .{ }^{16}$ All of these variables should help to capture the economic differences across U.S. counties at the start of the Great Depression.

We cannot use pre-existing values when we examine the impact of New Deal grants because such federal spending was unprecedented in 1930. Because migration flows during the 1930s may have affected New Deal spending decisions, we develop an instrumental variables approach that mitigates the endogeneity bias. Therefore, after estimating a simple ordinary least squares equation to establish the baseline correlations between net migration and the demographic, environmental, and New Deal spending variables, we turn to a two stage least squares approach that seeks to correct for the endogeneity of the New Deal spending. Finally, given that migration flows in the various counties may have been interrelated, we then expand the analysis to consider spatial correlations in the errors and considerations of geographic spillovers.

\section{Empirical Results}

To establish a baseline for comparison, we begin with a simple OLS analysis. Table 2 reports the OLS estimates for the New Deal variables under a variety of specifications. Public works and relief spending, under the OLS specification, were strongly associated with net in-migration and AAA spending 
was strongly associated with net out-migration. In the most basic model where net migration is estimated only as a function of the two grant categories, an additional annual per capita dollar of public works and relief spending was associated with an increase in the average annual net migration rate of 0.22 people per thousand. In contrast, an additional dollar of AAA spending was associated with net out-migration of 0.38 people per thousand. The signs of the relationships are robust to the inclusion of additional correlates, although the magnitudes are less in absolute value as we control for the additional variables. Once the other correlates and state effects are added, the public works coefficient falls to 0.178 , while the AAA coefficient becomes smaller at -0.108 . To put these effects into perspective, a one-standarddeviation increase in public works/relief spending would have increased net migration by 0.18 standard deviation. A one-standard-deviation increase in AAA spending would have caused net migration to fall by 0.08 standard deviation.

Because migration flows, or unobserved variables correlated with migration, might have influenced the distribution of New Deal grants, we might suspect the OLS estimates are biased. A priori, it is difficult to predict the direction or magnitude of the endogeneity bias. If out-migration was associated with economic distress during the 1930s, local officials may have sought greater New Deal funds from the federal government to alleviate the local unemployment situation and to stave off a continuing exodus of the workforce. Roosevelt's "relief, recovery, and reform" mantra would suggest that federal officials targeted funds to alleviate such economic problems. In fact, Fleck (1999b, 1999c, 2001a) and Fishback, Kantor, and Wallis (2003) find that both relief and public works spending were positively related to unemployment in 1930. To the extent that out-migration was a symptom of unfavorable economic conditions, we might expect federal officials to have distributed more funds to areas where people were more likely to leave than to arrive. Thus, the endogeneity bias might have been negative, causing the OLS coefficient to understate the positive effect that public works and relief spending had in attracting migrants.

Alternatively, the endogeneity bias could have gone the other way. Increased in-migration placed greater pressure on public facilities, such as schools and sanitation and water systems, which would have 
encouraged local officials to lobby for New Deal projects that would have alleviated these population pressures. In addition, if migrants into a county misestimated the employment opportunities in their new homes, their arrival might have contributed to greater unemployment and the need for federal New Deal assistance. However, the tendency for local relief officials to restrict non-residents' relief certification was likely to have mitigated this effect.

It is also likely that the AAA variable is endogenous, but the direction of the bias is unclear. Unlike the relief programs, the objective of the AAA was to limit national production of various commodities as a means to raise farm-gate prices. The parameters were designed with national prices and production in mind and, therefore, were not explicitly tied to local problems. The officials' parameter choices, however, might have been indirectly influenced by local conditions because national AAA parameters depended on the need to raise prices for specific crops. Since crop mix varied substantially across the country, and since the distress in specific crops may have been felt more heavily in some areas than in others, local agricultural conditions may have indirectly influenced the policy parameters that determined the distribution of AAA funds. Thus, to the extent AAA officials were seeking to raise prices by reducing production, they may have seen reductions in production caused by the out-migration of farmers as a means in itself to limit supply and, thus, saw less of a need to provide AAA funds. Under these conditions, the OLS coefficient of the AAA variable is likely biased upward. On the other hand, federal officials may have seen out-migration as a sign of distress and, thus, more reason to find ways to prop up farmers in those areas. In this case the OLS coefficient would be biased downward.

\section{V.1 Instrumental Variables}

To correct for the endogeneity biases of the New Deal variables, we follow a two stage least squares (2SLS) approach. Since the success of this empirical strategy depends on the credibility of the instruments that are chosen, we follow a stringent set of criteria for choosing suitable identifying instruments. First, the instruments must have been determined prior to the decisions made about New Deal spending and migration to avoid the potential for simultaneity bias. Second, to insure that the variables have power and make sense in the first-stage regression for which they are primary instruments, 
the coefficients must have the predicted signs in the appropriate first-stage New Deal regression and the effects must be both economically and statistically significant. Third, it must be the case that a series of tests, described below, cannot reject the hypothesis of no correlation between the identifying instruments and the estimated 2SLS error term of the second-stage migration equation. In other words, we are testing whether the instruments themselves have been inappropriately omitted from the migration equation.

There is an extensive literature on the geographic distribution of New Deal spending that suggests that New Deal officials responded in part to political considerations when making their allocation decisions. ${ }^{17}$ Robert Fleck (1999a), Fishback, Haines, and Kantor (2003), and Fishback, Horrace, and Kantor (forthcoming 2005) have had success using some of these political variables as instruments in studies of unemployment statistics, infant mortality, and retail sales growth, respectively. Of the group of instruments that have been proposed in the literature, only one variable meets the requirements that we have laid out above. Gavin Wright (1974) originally suggested that New Deal officials could reap a relatively larger marginal political benefit by spending an additional dollar in areas where voters were more likely to switch their party loyalties from one presidential election to another. Wright operationalized this idea using the standard deviation of the percent voting Democrat in presidential elections from 1896 to 1932 , but to avoid simultaneity problems in our analysis we calculate the standard deviation through the 1928 election. Nearly every study of New Deal spending has found this swingvoting measure to be an important determinant of the distribution of spending both at the state and the county level and it has an important positive effect on public works and relief spending in the first-stage analysis here. ${ }^{18}$ The question remains as to whether it is correlated with the error term of the second-stage net migration equation. There is no possibility that net migration in the 1930 s would have influenced presidential voting prior to 1929. On the other hand, should the variable be included as a regressor in the net migration equation or could it be correlated with unobservables in this second-stage equation? Our sense is that New Deal officials focusing on re-election would have been interested in the volatility of Democratic support, but that this would not carry over to the migration decisions of individual voters, particularly since we are controlling for the mean percent voting Democrat for president from 1896 to 
1928 in the net migration equation. People might be interested in moving to areas where there is a substantial community of politically like-minded voters, but after controlling for the mean, we do not believe that the volatility of that support would be particularly important to them.

A number of scholars have used natural resource endowments or physical characteristics as instruments in cross-sectional analyses in part because these factors were established long before the economic decisions under consideration in the research were made (see, e.g., Frankel and Romer 1999; Hoxby 2000). The presence of a major river in a county, for example, likely influenced public works and relief spending because the potential for flooding and the requirements for dredging and docks and other public services along the river provided local officials with ready-made projects that they could propose to federal New Deal administrators. ${ }^{19}$ More major rivers in a county meant more public works opportunities. In the case of agriculture, rivers were likely to influence the types of crops chosen and, hence, the pattern of AAA spending.

To create a useful instrument, we had to look beyond the mere presence of a river because every county in the United States has at least one river, and often many more, within its boundaries. Therefore, we developed three variables describing each county's access to "major" rivers because the size of dredging and port projects was likely to increase as the rivers increase in size. Our first definition of a major river is one that passes through 50 or more counties, which includes only the Ohio, Mississippi, and Missouri Rivers. For this category, the variable records the number of these three major rivers that passed through the county. The second variable measures the number of rivers in the county that pass through 21 to 50 total counties and the third variable measures the number of rivers in the county that pass through 11 to 20 total counties. The three groupings captured nearly all of the major rivers in the U.S. ${ }^{20}$ Could the rivers have influenced net-migration decisions? Certainly, rivers influence the location of cities, farming decisions, and economic activity, which, in turn, may influence migration. However, many of the avenues by which the presence of rivers would have influenced net migration - population growth in the prior decade, economic activity, urbanization, farm structure, state fixed effects, home ownership, etc - are controlled for in the second-stage migration equation. Thus, for the river variables to be unsuitable 
instruments, they would have to have an additional influence on the migration equation error term above and beyond these other control factors. It might seem that river travel would have influenced the costs of moving, but the expansion of the rail network and the automobile was likely to have reduced the role of river travel in migration by 1930 . River travel by this time was more oriented toward freight traffic than passenger traffic.

In their analysis of the determinants of 18 New Deal programs, Fishback, Kantor, and Wallis (2003) found that the elasticity of per capita AAA spending with respect to average farm size in 1929 was larger than nearly every other elasticity among all the programs. Net migration during the 1930s obviously could not have influenced average farm size in 1929, but we need to consider whether average farm size belongs in the net migration equation or whether it might be correlated with unobservables in the equation. At first blush it would seem that farm scale could have influenced the course of agricultural development during the 1930s and, thus, could have influenced net migration. However, the likely mechanism through which farm size would have influenced net migration is through income opportunities. But income opportunities have largely been controlled in the regression with the inclusion of unemployment variables in 1930, retail sales per capita, farm ownership, crop failures, and a dummy variable measuring whether the county experienced the Dust Bowl during the 1930s (see Hanson and Libecap, 2004).

The final instrument we use is the available water capacity (AWC) of the soil within the county. Generally speaking, AWC is a measure of the amount of water that the soil makes available for plant use. ${ }^{21}$ We expect soil quality to be an effective instrument for AAA spending since public policy decisions were unlikely to affect the physical nature of soil. Again the question arises whether certain soil types were more affected by the climatic events of the 1930s, which, in turn, may have influenced migration. What mitigates the direct influence of soil quality on migration is the inclusion of a set of variables measuring precipitation and drought during the 1930s, their interactions with the level of agricultural activity in the county, and the Dust Bowl dummy variable. 
There is reason to believe that each of the instruments influences at least one New Deal policy, but there may be concern that there still exists correlation between the identifying instruments and the error term of the second-stage migration equation, even after controlling for the major determinants of net migration. We believe that the set of independent variables in the equation foreclose the avenues for such correlation, but since the true error term is unobservable, there is no way to eliminate this concern fully. To mitigate this concern, however, we tested the hypothesis that the group of identifying instruments are uncorrelated with the 2SLS estimates of the migration error term (Hausman 1983, 433; see also Greene 2003, 413-14). We performed these tests with a variety of combinations of instruments and in no case did the test suggest that the identifying instruments as a group had been inappropriately omitted from the migration equation. As a final check on the robustness of the results, we have estimated the model using various combinations of the instruments so that the reader can readily see how the coefficients on public works and relief spending and on AAA spending are affected by changes in the set of instruments used.

\section{V.2 2SLS New Deal Results}

Table 3 reports the 2 SLS estimates from the net migration equation, along with the first-stage results of the relief/public works and AAA equations using the six instruments described above. The coefficients of the instruments in the first-stage regressions are generally consistent with our expectations. Greater volatility of Democratic voting at the county level and the presence of rivers had strong positive effects on public works and relief spending, while better quality soil as measured by AWC caused such spending to be lower. ${ }^{22}$ Larger average farm size, better soil quality, and access to the Ohio, Mississippi, or Missouri Rivers had a positive and statistically significant impact on AAA spending. F-tests show that we can reject the hypothesis that the coefficients of the identifying instruments were simultaneously zero at the 1 percent level in each equation. Finally, we performed Hahn and Hausman (2002) tests for weak instruments and found no sign that the instruments were weak.

The second-stage 2SLS coefficients of the New Deal variables are similar in sign to the OLS results, but the magnitudes of the 2SLS effects are larger in absolute value. As expected, relatively more spending on public works and on relief to the unemployed were associated with net in-migration. The 
public works and relief 2SLS coefficient is nearly triple the size of the OLS estimate. An additional dollar of public works and relief spending increased net in-migration by 0.52 people per thousand. The effect of a one-standard-deviation increase in public works and/or relief spending of $\$ 20$ would have led to a .54 standard deviation increase in net migration. Note that a relative increase in net migration could have occurred either because more people entered the county or relatively fewer people left. Given that state and local officials who certified workers for emergency work seem to have established de facto residency requirements, it may be that greater public works and relief spending did more to encourage workers to stay in their home counties than to attract people from other counties that may have received relatively less New Deal funding.

Both the OLS and 2SLS coefficients show that relatively more AAA spending was associated with out-migration. The results suggest that AAA spending likely contributed to an excess pool of farm workers, sharecroppers, and tenants who migrated out of agricultural areas as the AAA encouraged a reduction in the amount of land under production. This outflow of farm workers more than offset any effects that AAA benefit payments had on reducing out-migration by farm owners and tenants who were recipients of the payments. The AAA effect on net out-migration was larger in absolute value under the 2SLS model, such that a one-dollar increase in annual per capita AAA spending was associated with net out-migration of 0.18 people per thousand. A one-standard-deviation increase in AAA spending of \$14 would have caused a reduction in the net migration rate of 0.13 standard deviation. The magnified 2SLS effect indicates that the endogeneity bias in the OLS coefficient was likely positive, suggesting that AAA officials might have treated out-migration from a region as a signal that they did not have to spend as much on benefit payments to reduce agricultural production since the exodus of people from the county was already contributing to lower output.

Table 4 reports the sensitivity of the results to instrument selection by providing a detailed comparison of the results under different instrument combinations. The public works and relief 2SLS coefficients are consistently positive and larger than the OLS coefficient under all instrument combinations. The 2SLS AAA coefficients are larger, in absolute value, than the OLS coefficient. The 
public works and relief coefficients are larger and more precisely estimated when the volatility of Democratic voting is included, while the inclusion of the rivers variables tends to dampen the coefficient. The AAA coefficient is more precisely estimated when the average farm size variable is included, and its inclusion tends to diminish the negative effect AAA spending had on net migration.

\section{Controlling for Geographic Spillovers}

When empirically estimating the determinants of inter-county migration, one potential consideration is the spatial proximity between the geographic areas from where migrants came and to where they went. When people were considering a move, they likely compared the level of economic activity and New Deal spending in their home county with the situation in other places across the United States. Further, there may be unobservable factors influencing net migration that potentially are correlated with the unobservable factors in other counties. Since the vast majority of migrations are over shorter distances, it is likely that net migration will be more influenced by economic activity in nearby counties and that the correlations in unobservables will be stronger for unobservables in nearby counties. We control for these "spatial lags" in the errors using distance-based weights, and account for the endogeneity of our estimation, using methods developed by Kelejian and Prucha (1998).

To examine this relationship we have explored taking into consideration spatial correlations in the error term and also the impact of economic activity (exogenous retail sales per capita, $\mathrm{Y}$ ) in nearby counties. The new equation to be estimated becomes:

$$
M_{i}=a_{0}+a_{1} Y_{i}+a_{1}{ }^{*} g_{i}\left(Y_{j}, i \neq j\right)+a_{2} R_{i}+a_{3} A_{i}+a_{4} \Delta P_{20-30 i}+\Sigma_{k} a_{k} D_{i}^{k}+\Sigma_{n} a_{n} E_{i}^{n}+a_{s} S+\mu_{i}
$$

where $g_{j}\left(Y_{j}\right)$ is a distance-based weighted average of the exogenous retail sales in the counties $j$ that neighbor county $i$ and $\mu$ is the error. ${ }^{23}$ Spatial spillovers in the errors can be modeled as:

$$
\mu_{\mathrm{i}}=\rho \mathrm{g}_{\mathrm{i}}\left(\mu_{\mathrm{j}}, \mathrm{i} \neq \mathrm{j}\right)+\xi_{\mathrm{i}}
$$

where $\xi_{\mathrm{i}}$ is a zero-mean disturbance with variance $\sigma^{2}$, and $\rho$ is a scalar spatial autoregressive parameter. Equation (4) implies that the error $\mu_{i}$ is a function of errors in neighboring counties $j \neq i$. For 
computational parsimony, we assume that the spatial relationships, g, are equivalent in equations (3) and (4). We assume that $g_{i}$ is a weighted-average function and, as a result,

$$
g_{i}\left(\mathrm{Y}_{j}, i \neq j\right)=\sum_{j}^{n} \alpha_{i j} Y_{j}, \mathrm{j}=1, \ldots, n, \text { where } \sum_{j}^{n} \alpha_{i j}=1 \text { and } \alpha_{i i}=0
$$

The requirement that $\alpha_{i i}=0$ ensures that the county of interest i is not spatially correlated with itself and the requirement that the $\alpha_{i j}$ sum to one is a normalization so that relative (and not absolute) relationships between counties matter. We select the weighting parameters $\alpha_{\mathrm{ij}}$ based on geographic distance between counties, a commonly accepted parameterization in the spatial analysis literature. For example, Attfield et al. (2000) use geographic distance parameterizations to test the growth rate convergence hypothesis across U.S. states.

Thus,

$$
\alpha_{i j}=1 / d_{i j}\left[\sum_{j} 1 / d_{i j}\right]^{-1} \text { for } d_{i j}<d^{*} \text { miles; } \alpha_{i j}=0 \text { otherwise }
$$

where $d_{i j}$ is the distance between the seats of counties i and $\mathrm{j}$, and $d^{*}$ is a maximal distance or "cutoff" beyond which spatial effects are zero. We experimented with cutoff distances of 100, 200, and 600 miles, meaning that counties with county seats beyond that distance received a weight of zero. ${ }^{24}$ We have two reasons for imposing the cutoff distances. First, short moves across county boundaries were the most likely, as potential migrants were able to acquire more accurate information about opportunities in close neighboring counties and were likely to find it less personally daunting to move nearby (Schwartz 1973). We know from the 1940 Census that approximately 60 percent of those who said they moved between 1935 and 1940 moved within the same state. Second, consistent estimation requires that the spatial weighting matrix be sparse (Kelejian and Prucha 1999, Assumption 3). Imposing a cutoff of up to 600 miles is theoretically appealing, because it provides the sparseness necessary for consistent estimation of the spatial parameter, $\rho$. Moreover, Assumption 2 of Kelejian and Prucha (1999) requires that $|\rho|<1$. The 200-mile ensures that our estimate of $\rho$ satisfies this condition, although the 600-mile cutoff does not. ${ }^{25}$ 
Stacking observations in the main equation (3) and the error process equation (4) yields:

$$
\begin{aligned}
& M=a_{0}+a_{1} Y+a_{1}{ }^{*} W Y+a_{2} R+a_{3} A+a_{4} \Delta P_{20-30}+a_{k} D+a_{n} E+a_{s} S+\mu \\
& \mu=\rho W \mu+\xi
\end{aligned}
$$

where $\mathrm{W}$ is an $(n \times n)$ spatial weighting matrix, consisting of typical element $\alpha_{i j}$. Under suitable conditions, outlined in Kelejian and Prucha (1999) and satisfied here, the system is amenable to a generalized two stage least squares (G2SLS) procedure, which produces consistent estimates of the parameters. A discussion of the estimation procedure is outlined in Appendix II.

\section{VI.1 Generalized Two Stage Least Squares Results}

Table 5 offers a comparison of results from the generalized two stage least squares estimation in which we account for spatial correlation in the errors and then include a spatial weighting of economic activity in nearby counties. ${ }^{26}$ Under all of the specifications in Table 5, the magnitudes and statistical inferences related to the New Deal grants are similar to what we found under the 2SLS model. Public works and relief were associated with in-migration, while AAA spending was associated with outmigration.

When we include neighbors' retail sales directly in the equation, we see very little change in the coefficient on per capita retail sales in the county of interest. Thus, the impact of an additional dollar of per capita retail sales leads to an 0.01 increase in the net migration rate, whether we control for the neighbors' retail sales or not. Directly controlling for economic activity in neighboring counties reinforces the importance that economic opportunity plays in the migration decision. Holding retail sales in county i constant, a dollar increase in average retail sales in nearby counties would have been associated with a -0.008 change in the net migration rate. The coefficient is statistically significant at the 10 percent level only in the specification that includes neighboring counties out to 200 miles, however. Thus, relatively more people would have moved to county i if either economic activity increased in that county or if other neighboring counties experienced decreased activity. 


\section{Significance of the New Deal in Explaining Net Migration}

Migration is a complex phenomenon with a variety of determinants, so to put the importance of the New Deal into proper perspective, we estimate how much of the differences in net migration across counties can be explained by the differences in New Deal spending across these same counties. We split the sample into the 931 counties that experienced net in-migration and the 2117 counties that experienced net out migration. We then determined the means for the in-migration and out-migration samples. The mean net migration rate for the counties experiencing net in-migration was 13 , while the mean for the net out-migrant counties was -12.8 per thousand. We then performed a decomposition of the difference in the means between the two groups. The decomposition shows the percentage of the difference in net migration rates between the two groups of counties that can be explained by the average differences in the means of each independent variable. It combines the marginal effects measured by the coefficients with the relative size of the variables' differences across the two groupings of counties. The decompositions were performed for the OLS and 2SLS from Table 3 and the G2SLS coefficients with spatial corrections out to 100 miles in Table 5 .

The decompositions show that the New Deal programs have economically significant power in explaining the net migration patterns across counties. The mean annual public works and relief spending was $\$ 23.5$ in net in-migration counties compared with $\$ 15.5$ in net out-migration counties. This $\$ 8$ difference accounts for 5.51 percent to 16.3 percent of the difference in average net migration rates between the two types of counties, depending on the specification. Another way to describe the effect is to consider the effect of a one-standard-deviation change in public works and relief spending. A onestandard-deviation change of $\$ 20$ per capita contributed to a 0.18 to 0.50 standard deviation increase in the net migration rate. This effect is among the largest that we find for any variable in the system.

Meanwhile, the AAA grants had smaller but still economically important effects, possibly because of the countervailing migration incentives created for farm owners and farm workers. The counties with net in-migration received an annual average of AAA grants of about $\$ 4$ per person 
compared with an annual average of $\$ 11$ per person in areas with net out-migration. This difference in average AAA spending explains between 2.9 to 4.9 percent of the difference in net-migration rates between the two types of counties. A one-standard-deviation increase in AAA spending per capita of \$14 contributed to a -0.05 to -0.13 standard deviation reduction in the net migration measure.

\section{Other Determinants of Inter-County Migration}

The New Deal was only one of a large number of factors that influenced migration during the 1930s. Our analysis reinforces a finding in other studies that economic opportunity is important to the migration decision. Our analysis also adds new insights into the effects of geography and climate on the choice to migrate. Table 6 summarizes the results from various specifications.

As in many migration studies, measures of economic opportunity have the anticipated effects. There was more net in-migration (less out-migration) in counties with higher retail sales per capita in 1929 (our proxy for income). The difference in average retail sales between the group of counties experiencing positive net migration and the group of counties with negative net migration explains between 5.2 and 6.9 percent of the average differences in net migration between the two groups. When we add the impact of neighboring counties, holding constant the value in the county of interest, a reduction in retail sales in nearby counties explains about 4.9 percent of the difference in net migration between the two groups. Areas with higher homeownership rates and with lower shares of the population unemployed and laid off in 1930 experienced more net in-migration, although the unemployment and layoff effects are statistically insignificant. ${ }^{27}$ Farm areas where there were a higher proportion of owneroperated farms and areas with more farm failures in 1929 experienced out-migration.

Bogue, et. al. have suggested that blacks were moving out of the South during the 1930s. There are signs that southern counties with relatively higher black population shares experienced net outmigration, while areas outside the South with relatively larger black population shares experienced inmigration. At the margin, areas with a higher percentage foreign-born population experienced net inmigration. The 1930s appears to have slowed or even slightly reversed the long-term U.S. pattern of net 
in-migration into urban areas. Counties that had relatively greater urban populations and that had larger populations were more likely to experience net out-migration, although the coefficients are not statistically significant. Counties with a higher share of the population belonging to formal religious denominations tended to experience out-migration.

The results of the age distribution variables suggest that young adults may have been moving to exploit mismatches between the labor force requirements and the available working population in particular counties. Areas with a larger percentage of the population aged 10 to 19 in 1930, the group entering the workforce for the first-time, experienced more out-migration, while areas with a larger percentage of the population aged 55-64, the age group most likely to be exiting the workforce, experienced in-migration. ${ }^{28}$ In the decompositions between in-migration and out-migration counties, these age effects, respectively, contribute to explaining up to 17.3 percent and 9.1 percent of the differences in net-migration rates.

Migration studies suggest that prior movers are more likely to move again than stayers and that migration to areas tends to display persistence and path dependence across decades. Although we were unable to get county measures of net migration in the 1920s, we used population growth from 1920 to 1930 as a proxy for prior migration. The population growth coefficient showed strong persistence of migration trends from the 1920s.

The inclusion of a wide variety of climactic and geographic variables offers an opportunity to examine what people in the 1930s considered amenities and disamenities. The Atlantic and Gulf of Mexico coastal counties tended to attract more in-migrants than out-migrants, while counties with access to the Pacific Coast were associated with net out-migration, all else equal. Areas with more lakes attracted net in-migration, while counties with larger land areas were associated with out-migration. People appear to have been dissatisfied with regions with more variation in elevation, as a greater range in the elevation within the county was associated with out-migration. While controlling for elevation range, counties with higher maximum elevations were associated with in-migration. There also appears to have been a strong southern trend in migration. The coefficient on latitude suggests a movement to more 
southern areas. The latitude effect is present when state effects are excluded. There is no effect of longitude until state effects are removed from the model, which leads to signs of westward movement.

The 1930s seems to have been a period of climatic disasters, of which the Dust Bowl was only one. Given the greater importance of climate to farming, we included interactions between climate and the percentage of a county's land in agricultural use. In areas where farms were less important, greater average precipitation and increases in the number of months of extreme and severe wetness were associated with out-migration. In contrast, the more acreage of land in farms, the more likely was inmigration to be associated with greater average and extremes in precipitation. After controlling for latitude, higher temperatures had little effect on net migration in nonfarm areas and was associated with out-migration in farm areas. The temperature variable is sensitive to specification. When latitude is excluded from the analysis, warmer temperatures are associated with in-migration. ${ }^{29}$

Probably the most infamous climate-related event of the 1930s was the Dust Bowl disaster so vividly documented in Steinbeck's The Grapes of Wrath. Zeynep Hansen and Gary Libecap (2004) argue that the Dust Bowl was the result of a combination of inappropriate farming techniques, extreme or severe drought, and high winds. When we include their measure of Dust Bowl counties, the Dust Bowl counties were associated with an out-migration rate that was from 7.5 to 15.6 greater than in other counties. Given that the Dust Bowl counties were limited to relatively few counties, the Dust Bowl's effect in the decomposition is not as large, explaining from half a percent to 1.1 percent of the difference in the average net migration between in-migration and out-migration counties. In general, months of severe or extreme drought are not statistically significantly associated with net out-migration. This finding is suggestive that drought alone was not enough to cause net migration. It had to be associated with inappropriate farm techniques or with high winds as well.

\section{Conclusions}

The Great Depression was an extraordinary event in the economic history of the United States. There were many factors influencing net migration and our study of county-level migration trends 
allowed us to examine many previously unexamined features of net migration. As millions lost their jobs and inevitably became less economically tied to their communities, a significant number of people responded to the geographic differences in economic opportunity by moving. The patterns of net migration show that they typically moved out of areas with relatively lower per capita retail sales. Counties where home ownership opportunities were greatest in 1930 were associated with net inmigration. The different age structures across counties may have led to age-related geographic mismatches between the relative demand and supply of workers at different ages. Thus, areas with larger shares of young adults entering the workforce for the first time experienced out-migration, while areas with larger shares of adults on the cusp of retirement experienced more in-migration. Some of the movements during the 1930s were continuations of population growth trends from the 1920s. However, it appears that the long-term pattern of net migration into urban areas was halted during the 1930s.

The exodus from the Dust Bowl made famous by Steinbeck's story of the Joad family appears to have been the result of an unusual mixture of drought, wind, and improper farming techniques, as emphasized by the work of Hansen and Libecap. Measures of drought in other areas did not have much of an impact on net migration, while areas with excessive or severe episodes of wetness in farm areas drew in-migrants. The population appeared to be drifting southward and there were moves toward coastal counties in the southeast.

In response to the horrendous economy, the Roosevelt administration developed a variety of New Deal programs that caused the federal government to distribute grants to all communities in the United States, although the size of the grants and the mix of purposes varied substantially from county to county. Estimating the impact of these grants is complicated by potential endogeneity to the extent that the New Deal administrators were using net migration as one of many metrics in their decisions on how to distribute the grant funds. Our OLS estimates of the relationships establish a baseline for the fundamental relationship between net migration rates and New Deal spending. We attempt to correct for endogeneity bias using a 2SLS approach. Since we cannot know the true unmeasured error term in the second-stage migration equation, we cannot know for sure if the identifying instruments are correlated with that error. 
However, the control variables in the second-stage equation might already capture the avenues by which the identifying instruments might be correlated with net migration. The econometric tests available suggest that the identifying instruments have not been inappropriately omitted from the migration equation itself. Ultimately, the 2SLS estimates have the same signs as the OLS estimates and imply that the OLS estimates provide a lower bound estimate of the absolute value of size of the effects. However, the size of the 2SLS effects are sensitive to the choice of instruments and so we can only offer a range of estimates.

The type of grant distributed to the counties mattered greatly. Greater spending on public works and relief clearly had a strong positive effect on attracting migrants. The provision of emergency public employment allowed many of the unemployed to find temporary haven and, thus, avoid having to leave their homes. In addition, the building of civil infrastructure potentially stimulated economic opportunities that reduced out-migration and may have even encouraged people to move into areas that had relatively higher New Deal public works spending.

Not all New Deal programs drew people in. The AAA programs designed to reduce acreage were associated with net out-migration, contributing to the declines in the farm population that had begun in the early 1900s. The AAA payments to landowners may have induced a number of farmers who had previously planned to abandon farming to stay the course. However, this effect apparently was more than offset by a trend toward greater out-migration by tenants, sharecroppers, and farm workers. The AAA payments to take land out of production were targeted more towards farm-owners and large-scale farmers, while the reduction in the acreage they were planting likely led to a reduction in farm labor demand. The AAA association with out-migration suggests that the AAA program contributed to creating a pool of labor that was pushed out of agricultural areas.

Robert Moffit's (1992) survey of location responses to modern welfare benefits suggests that studies using individual-level data have been more likely to find migration effects among the poor than studies using more aggregate data. Therefore, we might expect to find stronger marginal effects for the unemployed population if we were able to study individual-level data. On the other hand, it is important 
to look at the county aggregates because the New Deal was not a set of programs designed simply to alleviate poverty or unemployment. The New Deal provided employment for a variety of workers. When the national unemployment rate reached 25 percent by 1933, the ranks of the unemployed included many who had never anticipated such dire straits. Yet, the public works and relief programs employed large numbers of skilled workers and opened up whole new regions for economic development. People moved in order to capture a piece of this economic growth. 


\section{Appendix I}

\section{Data Appendix}

The new estimates of net migration during the 1930s use the Census components of change method described in equation 1. The U.S. Bureau of the Census (1934a, b, c; 1936a, b; 1937; 1938; 1939; $1940 ; 1941 ; 1942)$ reported data on births, deaths, infant deaths, and stillbirths in each county during the 1930s. The change in population between 1930 and 1940 comes from ICPSR tape 0003, as corrected by Michael Haines).

It is well known that there was substantial undercounting of births prior to the 1940s and that the extent of the undercounting varied geographically (Whelpton 1934; U.S. Federal Security Agency 1946; U.S. Bureau of Census 1945). To account for the birth undercount in our migration measure, we adjusted it to mitigate the bias created in the undercount of birth registrations. Whelpton (1934) and the U.S. Bureau of the Census (1945) compared birth registration records for the year prior to the census year to the number of children less than one year of age as reported in the 1930 and 1940 censuses, respectively, and estimated the extent of the birth undercounts for each state. For each state, then, we developed an adjustment factor that enabled us to scale up the births in each of the state's counties. We began with the Census's 1940 undercount figure for all births in the state (p. 106). We then interpolated values for each year back to 1930 using the difference between the undercount percentage for whites in 1940 and Whelpton's (p. 128) percentage for whites in 1930. Since Texas and South Dakota were not included in Whelpton's analysis, we assumed that the 1930 figure was 10 percentage points lower than the 1940 figure.

New Deal spending information is from the U.S. Office of Government Reports (1940). For the case of the AAA farm payments, we had information for 1933 through 1937. Assuming these funds were representative of the whole period's spending, we scaled the four year's of information to six years by multiplying by 1.5. New Deal spending per capita was created by dividing by the 1930 population. The retail sales information is from Historical, Demographic, Economic, and Social Data: The United States, 1790-1970, ICPSR study number 0003, as corrected by Michael Haines. We calculated 1929 population 
as 1930 minus the average change in population between 1930 and 1940; we did not use trends from 1920 to 1930 due to changes in county boundaries during the 1920 s. All monetary variables in our analyses were translated into 1967 dollars using the Consumer Price Index (CPI). For the New Deal funds, we used the average annual CPI over the period 1933 to 1939 (0.412) and 1933 to 1935 (0.4). ${ }^{30}$

Population in 1930, population growth during the 1920s, unemployment and layoffs in 1930, percent black, percent urban, percent of land on farms, percent foreign born, percent illiterate, percent homeowners, county land area, average farm size, percent farms owner-operated, and percent of cultivated acreage that failed are all from the 1920 and 1930 files in ICPSR study number 0003, as corrected by Michael Haines. The percentages of the population in each age group are from the Gardner and Cohen (1992) ICPSR study number 0020. "Dust Bowl” counties were obtained from Hansen and Libecap (2004). Church membership data come from the U.S. Bureau of Census, $\underline{\text { Census of Religious }}$ Bodies, 1926. The presidential voting variables - the mean and standard deviation of the Democratic share of the presidential vote from 1896 to 1928 - were calculated using information from the ICPSR's, United States Historical Election Returns, 1824-1968 (study number 0001). In some cases there were missing values for the percent voting for president, so we used averages from the contiguous counties in their place. The latitude and longitude of county seats are from Sechrist, "Basic Geographic and Historic Data” (ICPSR study number 8159). ${ }^{31}$

The climate data are available from the National Climatic Data Center (NCDR). Text files of the data were accessed from ftp://ftp.ncdc.noaa.gov/pub/data/cirs/ (August 2003). The NCDR reports historical monthly data by climate division within each state, so each county's climate information pertains to its respective climate division. In some cases a county was located within two or three divisions. In these cases, the county's climate information was calculated as the average across the climate divisions in which it was located.

Using maps we developed dummy variables for coastal access to the Atlantic coast, the Pacific coast, the Gulf coast, and to the Great Lakes. A county was considered on a coast if it touched the major body of water or was on a bay, sound, or major river that might be considered to have direct access. 
Thus, the Washington counties on Puget Sound are considered Pacific coastal counties by this definition. Counties on the Chesapeake and Potomac, the southern parts of the Hudson River, and the counties up to Philadelphia are considered Atlantic coast counties.

Roger Paine and Joe Johnson of the U.S. Geological Survey gave us a list of all the "streams" listed in the GNIS names topographical map database with all of the counties in which each stream was currently located. This information also can be obtained stream by stream through query at http://geonames.usgs.gov/pls/gnis/web_query.gnis_web_query_form as of August 2003. Streams is a broad definition including creeks and rivers. There were over 100,000 stream names in the data base. Each stream name has a numeric feature code as well as the name. Using the numeric feature code, we performed frequencies on the number of counties in which each stream was listed. We then developed a series of variables showing access to streams that ran through different numbers of counties. The riv51up is the number of rivers running through the county that ran through over 50 counties. Only the Mississippi, Missouri, and Ohio Rivers, ran through as many as 50 counties, and they are the major rivers in the Eastern and Midwestern United States. We included a second variable (riv2150) for access to rivers passing through 21 to 50 counties (includes the Red, Arkansas, Tennessee, Snake, Rio Grande, Canadian, Chattahoochie, Columbia, Brazos, Cumberland, Colorado, White, Cimarron, Des Moines, and James). Another dummy, riv1120, encompasses the next largest 53 rivers. Of the rivers passing through over 10 counties, most are considered navigable by modern definitions by the Army Corps of Engineers. The ones not listed as navigable are mostly western rivers and include the Niobrara, Sheyenne, Washita, Catawba, Cheyenne, North Canadian, Canadian, Smoky Hill, Alapaha, Big Sioux, Neches, Pecos, Wisconsin, Yellowstone, Des Moines, Rio Grande, Nueces, Platte, Big Black, Rio Brazos, Cimmarron, Wapsipinicon, and Sabine. The variable for riv0510 encompasses 384 rivers. The information on which waterways were navigable was provided by Amy Tujaque, who is a Survey Statistician for the Waterborne Commerce Statistics Center for the U.S. Army Corps of Engineers. We used a relatively coarse measure of access because the Geological Survey staff warned us that sometimes the same river might have multiple feature numbers. On the other hand, there are also quite a few stream names that 
appear multiple times but are clearly not connected. We examined the situation for the major rivers and found that this was not a significant problem for them.

The average water content measure from the 1990s came from the State Soil Geographic (STATSGO) Data Base for the Conterminous United at http://water.usgs.gov/lookup/getspatial?ussoils. Mickey Lynn Reed and Todd Sorensen converted the information to county data by using ARC-GIS mapping software to layer county boundaries over the basic data set of 78,518 polygonal land areas and create averages weighted by land area.

The data set consists of 3,048 counties and county/city combinations in the United States. The New Deal program information was reported for some combined counties. For example, the New Deal information was reported for all of New York City. Thus, in New York state, Bronx, King, New York, Queens, and Richmond counties were combined into New York City. Similar situations developed in other states. In Missouri the city of St. Louis and St. Louis County were combined. In Virginia we combined the following districts that were reported separately in the Census: Albemarle County and Charlottesville city; Allegheny County and Clifton Forge city; Augusta County and Staunton city; Campbell County and Lynchburg city; Dinwiddie County and Petersburg city; Elizabeth City County and Hampton city; Frederick County and Winchester city; Henrico County and Richmond city; Henry County and Martinsville city; James City County and Williamsburg city; Montgomery County and Radford city; Nansemond County and Suffolk city; Norfolk County with Norfolk city, South Norfolk city, and Portsmouth city; Pittsylvania County and Danville city; Prince George County and Hopewell city; Roanoke County and Roanoke city; Rockbridge County and Buena Vista city; Rockingham County and Harrisonburg city; Spotsylvania County and Fredericksburg city; Warwick County and Newport News city; Washington County and Bristol city; Arlington County and Alexandria city.

In some situations we had to combine counties because of the nature of the reporting of the birth and mortality data. In the early 1930s the census reported mortality and birth information separately for cities and for counties. In combining the rural county information with the city information, we discovered that several cities were located in two counties. In situations where the city was 90 percent or 
more in one county, we put it into that county. In other situations we combined the counties. Those include Russell and Lee counties in Alabama (Phenix City); Benton, Sherbourne, and Stearns counties in Minnesota (St. Cloud); Hancock and Seneca counties in Ohio (Fostoria); DeKalb, Fulton, Milton, and Campbell counties in Georgia (Atlanta); Edgcomb and Nash counties in North Carolina (Rocky Mount); Lehigh and Northampton counties (Bethlehem) and Beaver and Lawrence counties (Ellwood City) in Pennsylvania); Jefferson and Dodge counties in Wisconsin (Watertown); and James City and York counties in Virginia (Williamsburg).

For analyzing spatial correlations, we used maps from the 1930s to determine which counties were contiguous to each other; the largest number of contiguous neighbors for a single county was 14 . When developing the inverse distance spatial weighting scheme, we used the ICPSR data set 8159 created by Robert Sechrist. We found a number of errors in the latitudes and longitudes in ICPSR data set, which were corrected: Dutchess, NY latitude 41.45, Greene, PA longitude 80.12, Moultrie, IL latitude 39.35, Fulton IN latitude 41.07 longitude 86.15, Rock Nebraska longitude 99.32, Butte, SD latitude 44.38, Campbell, SD latitude 45.44, McCook SD latitude 43.39, Webster, GA latitude 32.04, Greene, NC latitude 35.28, longitude 77.45, Sampson NC latitude 35.0; Wake, NC latitude 35.45; Rains, TX latitude 32.52; Fulton, KY latitude 36.33; Custer, OK longitude 98.57; Carbon, MT longitude 109.2; Santa Fe, NM latitude 35.4; Mendocino, CA latitude 39.09, longitude 123.12; Multnomah, OR longitude 122.4. When measuring population growth from 1920 to 1930, we used the difference in log population between the two years. There were a number of counties that were formed from other counties by 1930 that did not exist in 1920. For those counties we determined the population growth rate for the entire area for 1920 and 1930 and then used the growth rate for the area as a measure of the growth rate for each of the counties in that area. For example, if one county from 1920 was broken into three counties by 1930 , we calculated the growth rate for the combination of the three 1930 counties and then used the combined growth rate for all three. Information on the 1920 population figures came from the ICPSR Tape corrected by Michael Haines. 
The South in this context is defined as the states with ICPSR codes from 40 through 56, including Alabama, Arkansas, Florida, Georgia, Louisiana, Mississippi, North Carolina, South Carolina, Kentucky, Maryland, Oklahoma, Tennessee, Texas, Virginia, West Virginia.

Using an Atlas, we developed dummy variables for coastal access to the Atlantic coast, the Pacific coast, the Gulf coast, and to the Great Lakes. A county was considered on a coast if it touched on the major body of water or was on a bay, sound, or major river that might be considered to have direct access. Thus, the Washington Counties on Puget sound are considered Pacific coastal counties in this definition. Counties on the Chesapeake and Potomac, the early parts of the Hudson river, and the counties up to Philadelphia are considered Atlantic coast counties.

We developed a series of variables to describe the elevation range and maximum elevation and information on the number of bays, lakes, beaches, etc., as reported in the USGS's Geographic Names Information System. The information was downloaded from http://geonames.usgs.gov/stategaz/index.html (August 2003). The data set describes features noted on small-scale topographical maps, including mouths of streams, lakes, valleys, summits, cliffs, bayous, beaches, etc. ${ }^{32}$ The Geographic Names Information System (GNIS) contains name and location information about almost 2 million physical and cultural features located throughout the United States and its Territories.GNIS was developed by the U.S.Geological Survey in cooperation with the U.S. Board on Geographic Names (BGN) to promote the standardization of feature names. GNIS is being compiled in phases. The first phase is complete for the entire U.S., and entailed the collection of names from Federal sources including large-scale USGS topographic maps, Office of Coast Survey charts, U.S. Forest Service maps, and digital datasets distributed by the Federal Communications Commission, the Federal Aviation Administration, and the U.S. Army Corps of Engineers. The second phase of data collection is complete or in progress for about $90 \%$ of the U.S., and captures names from State, locally, and other published current and historical maps, charts, and texts. The information was downloaded in August 2003 from http://geonames.usgs.gov/stategaz/index.html. 
The data set describes features noted on small-scale topographical maps, including mouths of streams, lakes, valleys, summits, cliffs, bayous, beaches, etc. Elevation was listed for a significant number of features in each county. We used this information to determine the maximum and minimum elevation listed and the range between the two figures. We did not try to calculate an average elevation because many of the features did not include information on elevation. Because of the lack of full coverage there may be some measurement error, but our sense from spot checks around the country is that the maximum and minimum elevations are reasonable depictions of those figures.

From the data set we calculated the number of summits and valleys to get a sense of the degree to which there were fluctuations in terrain. The original database includes the number of airports, arches, areas, arroyos, bars, basins, bays, beaches, benchs, bends, buildings, canals, capes, cemeterys, churchs, civils, cliffs, craters, crossings, dams, falls, flats, forests, gaps, guts, harbors, hospitals, islands, lakes, locales, militarys, mines, oilfields, parks, pillars, plains, postoffs, populated places, ranges, rapids, reserves, reservoirs, ridges, schools, springs, mouths of streams, summits, swamps, towers, trails, tunnels, valleys, wells, woods. For the purposes of our research we sought to avoid using man-made features, so we used only summits, bays, lakes, summits, valleys, mouths of streams, swamps, beaches, forests, and woods. Even in these cases there may have been changes wrought since the 1930s, so there is likely to be some measurement error for the natural features as they stood in the 1930s.

When we were working with the geography measures and the river measures, there were some county boundary changes between 1940 and 2000. In situations where new counties were carved from older counties, we have merged the new county information back in with the older counties. La Paz in Arizona was merged back in to Yuma county and Cibola county in New Mexico was merged back into from Valencia. [Broomfield, Colorado was formed in 2001 but had no streams listed.] Virginia developed a new set of independent cities and their information was merged back into the county/city combinations that we developed for the New Deal. We did not pay close attention to situations where parts of some counties were annexed to others, but we do not believe this to be a serious problem. In 
South Dakota Washabaugh county had been combined into Jackson county and Washington County had been combined into Shannon after 1940. To determine the geographic features for Washabaugh we used any features above latitude of 4.372694 from Jackson county. This may overstate some features in Washabaugh. For Shannon we took all features in Shannon county below latitude 43.30139. Information on county boundary changes since 1970 comes from

http://www.census.gov/geo/www/tiger/ctychng.html\#1970. 


\section{Appendix II}

\section{G2SLS Estimation Procedure}

1. Let matrix $\mathrm{Z}$ represent all the exogenous variables in the system, including the identifying instruments discussed in section V.I. Using $\mathrm{Z}$ as instruments, perform 2SLS on the migration equation, ignoring the spatial effects in the error process.

2. Defining the usual 2SLS residuals, $e$, calculate $\bar{e}=W e$ and $\overline{\bar{e}}=W \bar{e}$. Then, calculate

$\Omega=n^{-1}\left[\begin{array}{ccc}2 e^{\prime} \bar{e} & -\bar{e}^{\prime} \bar{e} & n \\ 2 e^{\prime} \overline{\bar{e}}_{m} & -\overline{\bar{e}}^{\prime} \overline{\bar{e}} & \operatorname{tr}\left(W^{\prime} W\right) \\ \left(e^{\prime} \overline{\bar{e}}+\bar{e}^{\prime} \bar{e}\right) & -\bar{e}^{\prime} \overline{\bar{e}} & 0\end{array}\right]$

and

$\omega=n^{-1}\left[\bar{e}^{\prime} \bar{e}, \overline{e^{\prime}} \overline{\bar{e}}, \bar{e}^{\prime} \overline{\bar{e}}\right]$

Define $\theta^{\prime}=\left[\rho, \rho^{2}, \sigma^{2}\right]$. A consistent estimate of $\rho$ is calculated by solving the non-linear system: $\left[\tilde{\rho}, \tilde{\sigma}^{2}\right]=\underset{\rho, \sigma}{\arg \min }[\omega-\Omega \theta]^{\prime}[\omega-\Omega \theta]$.

3. Pre-multiply the migration equation by $\left(I_{n}-\tilde{\rho} W\right)$. G2SLS proceeds by performing ordinary 2 SLS on the transformed equation. See Schmidt (1976, chapter 4) for details on ordinary 2SLS. 


\section{Appendix III}

\section{Comparisons of Estimates of Net Migration During the 1930s}

Our estimate of net migration offers an alternative to Gardner and Cohen's (GC) earlier estimates (available in ICPSR dataset 0020). They also used a residual technique based on the difference in population between 1930 and 1940 and an estimate of the natural rate of increase based on forwardcensus survival methods. ${ }^{33}$ Their estimates of the natural rate of increase were computed by applying the national survival rates from 1930 to 1940 for each age/sex/race group in the U.S. to the age/sex/race structure in each county in 1930. Since the survival method provides little guidance for the 0-9 age group, their estimate of net migration is for persons over the age of nine as of 1940, and the birth rate is removed from their migration calculations. Using alternative techniques they have also developed a rough estimate of net migration for the age group under 10. The correlation between their measure of net migration using all groups and using just those 10 and over is .995 . Given that GC express reservations about the inclusion of the 0-9 age group in their measure, we make comparisons of our estimates with their estimates for ages 10 and over.

Whelpton also provided estimates of the birth undercount for whites and nonwhites separately in 27 states for 1930 and the Census did so for all states in 1940. Therefore, we can also perform a more complicated adjustment. We do not focus on this estimate in the text because the estimates of the birth undercounts by race were not available for all states in 1930. The more complicated adjustment involves developing a measure of the weighted average of black and white undercounts using the percentages of whites and nonwhites in the population as the weights. Let

$$
\mathrm{U}_{\mathrm{jt}}=\mathrm{U}_{\mathrm{wj}} \mathrm{p}_{\mathrm{wjt}}+\mathrm{U}_{\mathrm{njt}} \mathrm{p}_{\mathrm{njt}} \text {, }
$$

where $\mathrm{U}$ is registered births as a percentage of the true births, the $\mathrm{j}$ subscript refers to the county, $\mathrm{t}$ is the year, and $\mathrm{w}$ is white and $\mathrm{n}$ nonwhite. After calculating these weights for 1930 and 1940, we calculate the average $U_{j}$ for the decade. We then adjust the births in each county by multiplying the inverse of $U_{j}$ by the number of births over the decade. In the states where there was no information on the black undercount in 1930, we calculated the black 1930 ratio as 


$$
\mathrm{U}_{\mathrm{nj} 30}=\mathrm{U}_{\mathrm{nj} 40}-\left(\mathrm{U}_{\mathrm{wj} 40}-\mathrm{U}_{\mathrm{wj} 30}\right) .
$$

Whelpton had no undercount information for Texas and South Dakota in 1930; therefore, we came up with an estimate of $\mathrm{U}$ in 1930 for both blacks and whites by subtracting 10 percentage points from the 1940 figure.

Comparisons of our new estimates with the GC estimates show that they are highly correlated. Each of our estimates has a correlation with the GC measure that exceeds .984. One method of comparing the measures of net migration is to sum the estimates across all counties for an aggregate net in-migration estimate for the entire U.S. Immigration statistics show that the number of immigrants to the U.S. was 528,422 during the 1930s (U.S. Census Bureau 1975, 105). We do not have very accurate statistics on emigrants, but the U.S. Immigration and Naturalization Service reported information on passenger arrivals and departures by airline and by sea (land travel across borders excluded). Arrivals minus departures between 1930 and 1940 were -18,018. If we focus only on aliens, net arrivals for aliens were $-35,415$. The GC estimate of net immigration for the U.S. as a whole is around $-340,000$ persons. Our county measures of net migration without adjustments for the birth undercount sum to over 1.8 million persons. After the simple adjustment for the birth undercount using the state averages, the adjusted measure of net migration that we use in the text sums to -193,000. After adjusting using racial differences in undercounting and racial population weights, the adjusted measure sums to $-93,000$.

Appendix Table III-1 offers a comparison of net migration rates at the state level based on our unadjusted measure, our adjusted measure, GC's measure, and a measure based on Census statistics for the period 1935 to 1940 . The latter measure is the difference between the number of people in the state in 1940 who claimed to have migrated into the state since 1935 minus the number of persons who had migrated to another state by 1940 but claimed residence in the state as of 1935 . To make the 1935-1940 measure comparable in magnitude to the others, we then multiplied the figure by 2 and divided by the population in thousands in 1930 . When we compare the state aggregates, our measures are slightly more correlated with the measure based on the 1935 to 1940 migration at around .94 and .95 than is the GC 
measure at 0.92 . The correlations of the state aggregates between our measures and the GC is .97 for the uncorrected measure and .99 for the measure adjusted for the birth undercounts.

When we compare our adjusted measure with GC's and the Census's 1935-1940 estimate, we see that all of the measures of net migration agree that the states with the highest rates of net in-migration include Florida, California, Nevada, Oregon, Delaware, Maryland, New Mexico, Washington, and Idaho. The largest out-migration rates were found in the Great Plains states of North Dakota, South Dakota, Oklahoma, Kansas, and Nebraska, and the southern states of Arkansas, Alabama, Mississippi, and Georgia.

We calculated the difference between our adjusted measure and the GC estimate and examined the counties in the tails of this distribution. Of the 25 counties where our measure overpredicts (relative to the GC measure) net out-migration, most of the counties are in the Plains states where droughts and the Dust Bowl drove many families off their farms. Of the 20 counties where we find far more in-migration relative to GC, seven were Texas oil boom counties. In this group of counties male employment in the oil industry rose 13 -fold from 565 to 7818 , while overall male gainful employment rose three-fold from 13,330 to 32,931 . In contrast, in a number of Texas counties where the oil boom started prior to 1930 , the difference between our estimate and GC's estimate was relatively small. The typical pattern in these counties was either no increase or a decrease in oil employment and little or negative change in employment.

Economic booms seem to explain the largest gaps between our migration estimates and GC's. Lea County, New Mexico nearly tripled its population when oil employment rose 10-fold. Grant, Washington, and Summit Counties, Colorado, and Mono, California experienced booms in construction employment. Storey, Nevada and San Miguel, Colorado experienced substantial increases in mining activity. Apache, Arizona experienced rapid growth in saw mill and lumber activity. There were four agricultural counties (Conejos and Costilla in Colorado and Daggett and San Juan in New Mexico) where there was very little population change but there were dramatic differences in the gap between migration estimates. We also have some counties (San Juan, Costilla, and Conejos, New Mexico) that experienced 
substantial population growth of 25 percent or more, but we have not as yet identified the reasons for the changes.

In sum, calculating migration rates of the 1930s involves accepting some degree of measurement error. Although constructed quite differently, however, our estimates and those of GC draw quite similarconclusions regarding the places people were moving to and from. As we mention above, the two measures are very highly correlated. In the text we have focused our analysis on our estimates, but if we had reported the regression results using the GC measure, the same basic conclusions would emerge. All of our regression results using the GC measure can be obtained from the authors. 


\section{Appendix IV}

\section{Discussion of Biases in Measuring Net Migration}

Some people have thought that there might be a bias in the methodology that we use that is unrelated to measurement error in births and deaths. The methodology that we use is a standard census methodology known as the components of change method. See the notes to series c25-c27 in U.S. Bureau of the Census (1975, p. 87). We show below that our method is the equivalent of calculating net migration as the sum of all in-migrants into the county in each year in the decade minus the sum of allout-migrants from the county across the decade. If someone is interested in net-migration in each year there is aggregation bias in our method in that we are summing across an entire decade. Someone who arrives in 1936 and leaves in 1937 is missing in both the 1930 and 1940 populations and therefore their effect on our measure of net-migration for the decade is zero. But this is true in the census survival method used by Gardner and Cohen as well and would also be problematic for the Census 1935-1940 measurement, which asks only location in 1935 and 1940. It is also problematic for much of the modern annual data if someone moves in and out in the same year because the typical question is where did you live last year.

The analysis below underlies footnote 8 in the paper. One reader was worried about births for families arriving after 1930 and deaths of people who arrive after 1930. We created a situation where there are 2 counties: counties 1 and 2 where county 2 represents all other counties. In Appendix Table IV-1, we show the decision tree for what happens to people starting in each county in 1930 and being born in each county after 1930 and add up the people there in 1930, the people there in 1940, the births, deaths, in-migration and out-migrations in between. We also matched up variable names to see how this works mathematically. For example ps 11 is someone in county 1 in 1930 who stayed in county 1 through 1940, p1m2s2, is someone in county 1 in 1930 who migrated to county 2 and stayed there through 1940 , p1m2m1 is someone in county 1 in 1930 who migrated to county 2 and then returned to county 1 by 
1940, p1m2d2 is someone in county 1 in 1930 who migrated to county 2 and then died there before 1940.

The b1 stands for someone born in county 1 after 1930, etc.

Using the variable names we can show how the various measures are associated with the decision tree.

From the perspective of county 1 treat all other counties as county 2.

Population in county 1 in $1930 \mathrm{P} 1,30$

$\mathrm{P} 1,30=\mathrm{ps} 11+\mathrm{p} 1 \mathrm{~m} 2 \mathrm{~s} 2+\mathrm{p} 1 \mathrm{~m} 2 \mathrm{~m} 1+\mathrm{p} 1 \mathrm{~m} 2 \mathrm{~d} 2+\mathrm{p} 1 \mathrm{~d} 1$

Population in county 1 in 1940, P1, 40

$\mathrm{P} 1,40=\mathrm{ps} 11+\mathrm{p} 1 \mathrm{~m} 2 \mathrm{~m} 1+\mathrm{b} 1 \mathrm{~s} 1+\mathrm{b} 1 \mathrm{~m} 2 \mathrm{~m} 1+\mathrm{p} 2 \mathrm{~m} 1 \mathrm{~s} 1+\mathrm{b} 2 \mathrm{~m} 1 \mathrm{~s} 1$.

Births in county 1,3040

$\mathrm{B} 1,3040=\mathrm{b} 1 \mathrm{~s} 1+\mathrm{b} 1 \mathrm{~m} 2 \mathrm{~s} 2+\mathrm{b} 1 \mathrm{~m} 2 \mathrm{~m} 1+\mathrm{b} 1 \mathrm{~m} 2 \mathrm{~d} 2+\mathrm{b} 1 \mathrm{~d} 1$

Deaths in 1 between 30 and 40

$\mathrm{D} 1,3040=\mathrm{p} 1 \mathrm{~d} 1+\mathrm{b} 1 \mathrm{~d} 1+\mathrm{p} 2 \mathrm{~m} 1 \mathrm{~d} 1+\mathrm{b} 2 \mathrm{~m} 1 \mathrm{~d} 1$

Outmigrants between 1930 and 1940 in 1

$\mathrm{O} 1,3040=\mathrm{p} 1 \mathrm{~m} 2 \mathrm{~s} 2+\mathrm{p} 1 \mathrm{~m} 2 \mathrm{~m} 1+\mathrm{p} 1 \mathrm{~m} 2 \mathrm{~d} 2+\mathrm{b} 1 \mathrm{~m} 2 \mathrm{~s} 2+\mathrm{b} 1 \mathrm{~m} 2 \mathrm{~m} 1+\mathrm{b} 1 \mathrm{~m} 2 \mathrm{~d} 2+\mathrm{p} 2 \mathrm{~m} 1 \mathrm{~m} 2+\mathrm{b} 2 \mathrm{~m} 1 \mathrm{~m} 2$

Inmigrants between 1930 and 1940 for 1

$\mathrm{I} 1,3040=\mathrm{p} 1 \mathrm{~m} 2 \mathrm{~m} 1+\mathrm{b} 1 \mathrm{~m} 2 \mathrm{~m} 1+\mathrm{p} 2 \mathrm{~m} 1 \mathrm{~s} 1+\mathrm{p} 2 \mathrm{~m} 1 \mathrm{~m} 2+\mathrm{p} 2 \mathrm{~m} 1 \mathrm{~d} 1+\mathrm{b} 2 \mathrm{~m} 1 \mathrm{~s} 1+\mathrm{b} 2 \mathrm{~m} 1 \mathrm{~m} 2+\mathrm{b} 2 \mathrm{~m} 1 \mathrm{~d} 1$

\section{NET MIGRATION CALCULATION in paper.}

Population in county 1 in 1940, P1, 40

$\mathrm{P} 1,40=\mathrm{ps} 11+\mathrm{p} 1 \mathrm{~m} 2 \mathrm{~m} 1+\mathrm{b} 1 \mathrm{~s} 1+\mathrm{b} 1 \mathrm{~m} 2 \mathrm{~m} 1+\mathrm{p} 2 \mathrm{~m} 1 \mathrm{~s} 1+\mathrm{b} 2 \mathrm{~m} 1 \mathrm{~s} 1$.

minus

Population in county 1 in $1930 \mathrm{P} 1,30$

$\mathrm{P} 1,30=\mathrm{ps} 11+\mathrm{p} 1 \mathrm{~m} 2 \mathrm{~s} 2+\mathrm{p} 1 \mathrm{~m} 2 \mathrm{~m} 1+\mathrm{p} 1 \mathrm{~m} 2 \mathrm{~d} 2+\mathrm{p} 1 \mathrm{~d} 1$

minus

Births in county 1,3040

$\mathrm{B} 1,3040=\mathrm{b} 1 \mathrm{~s} 1+\mathrm{b} 1 \mathrm{~m} 2 \mathrm{~s} 2+\mathrm{b} 1 \mathrm{~m} 2 \mathrm{~m} 1+\mathrm{b} 1 \mathrm{~m} 2 \mathrm{~d} 2+\mathrm{b} 1 \mathrm{~d} 1$ 
Plus

\section{Deaths in 1 between 30 and 40}

$\mathrm{D} 1,3040=\mathrm{p} 1 \mathrm{~d} 1+\mathrm{b} 1 \mathrm{~d} 1+\mathrm{p} 2 \mathrm{~m} 1 \mathrm{~d} 1+\mathrm{b} 2 \mathrm{~m} 1 \mathrm{~d} 1$.

This becomes

$\mathrm{NM} 13040=\mathrm{ps} 11+\mathrm{p} 1 \mathrm{~m} 2 \mathrm{~m} 1+\mathrm{b} 1 \mathrm{~s} 1+\mathrm{b} 1 \mathrm{~m} 2 \mathrm{~m} 1+\mathrm{p} 2 \mathrm{~m} 1 \mathrm{~s} 1+\mathrm{b} 2 \mathrm{~m} 1 \mathrm{~s} 1-\mathrm{ps} 11-\mathrm{p} 1 \mathrm{~m} 2 \mathrm{~s} 2-\mathrm{p} 1 \mathrm{~m} 2 \mathrm{~m} 1-\mathrm{p} 1 \mathrm{~m} 2 \mathrm{~d} 2-\mathrm{p} 1 \mathrm{~d} 1$

-b1s1-b1m2s2-b1m2m1-b1m2d2-b1d1+ p1d1+b1d1+p2m1d1+b2m1d1.

After Eliminating like terms not associated with migration:

$\mathrm{NM} 13040=\mathrm{p} 1 \mathrm{~m} 2 \mathrm{~m} 1+\mathrm{b} 1 \mathrm{~m} 2 \mathrm{~m} 1+\mathrm{p} 2 \mathrm{~m} 1 \mathrm{~s} 1+\mathrm{b} 2 \mathrm{~m} 1 \mathrm{~s} 1+\mathrm{p} 2 \mathrm{~m} 1 \mathrm{~d} 1+\mathrm{b} 2 \mathrm{~m} 1 \mathrm{~d} 1-\mathrm{p} 1 \mathrm{~m} 2 \mathrm{~s} 2-\mathrm{p} 1 \mathrm{~m} 2 \mathrm{~m} 1-\mathrm{p} 1 \mathrm{~m} 2 \mathrm{~d} 2-\mathrm{b} 1 \mathrm{~m} 2 \mathrm{~s} 2$

-b1m2m1-b1m2d2.

NET MIGRATION CALCULATION by summing all in-migrants and out-migrants and

subtracting one from the other.

Inmigrants over 3040 for 1

$\mathrm{I} 1,3040=\mathrm{p} 1 \mathrm{~m} 2 \mathrm{~m} 1+\mathrm{b} 1 \mathrm{~m} 2 \mathrm{~m} 1+\mathrm{p} 2 \mathrm{~m} 1 \mathrm{~s} 1+\mathrm{p} 2 \mathrm{~m} 1 \mathrm{~m} 2+\mathrm{p} 2 \mathrm{~m} 1 \mathrm{~d} 1+\mathrm{b} 2 \mathrm{~m} 1 \mathrm{~s} 1+\mathrm{b} 2 \mathrm{~m} 1 \mathrm{~m} 2+\mathrm{b} 2 \mathrm{~m} 1 \mathrm{~d} 1$.

\section{Outmigrants over 3040 in 1}

$\mathrm{O} 1,3040=\mathrm{p} 1 \mathrm{~m} 2 \mathrm{~s} 2+\mathrm{p} 1 \mathrm{~m} 2 \mathrm{~m} 1+\mathrm{p} 1 \mathrm{~m} 2 \mathrm{~d} 2+\mathrm{b} 1 \mathrm{~m} 2 \mathrm{~s} 2+\mathrm{b} 1 \mathrm{~m} 2 \mathrm{~m} 1+\mathrm{b} 1 \mathrm{~m} 2 \mathrm{~d} 2+\mathrm{p} 2 \mathrm{~m} 1 \mathrm{~m} 2+\mathrm{b} 2 \mathrm{~m} 1 \mathrm{~m} 2$.

NM1, 3040=

$\mathrm{p} 1 \mathrm{~m} 2 \mathrm{~m} 1+\mathrm{b} 1 \mathrm{~m} 2 \mathrm{~m} 1+\mathrm{p} 2 \mathrm{~m} 1 \mathrm{~s} 1+\mathrm{p} 2 \mathrm{~m} 1 \mathrm{~m} 2+\mathrm{p} 2 \mathrm{~m} 1 \mathrm{~d} 1+\mathrm{b} 2 \mathrm{~m} 1 \mathrm{~s} 1+\mathrm{b} 2 \mathrm{~m} 1 \mathrm{~m} 2+\mathrm{b} 2 \mathrm{~m} 1 \mathrm{~d} 1$

- p1m2s2-p1m2m1-p1m2d2-b1m2s2-b1m2m1-b1m2d2-p2m1m2-b2m1m2.

After comparing the two calculations, the difference is the following.

Difference $=2 \mathrm{~m} 1 \mathrm{~m} 2+\mathrm{b} 2 \mathrm{~m} 1 \mathrm{~m} 2-\mathrm{p} 2 \mathrm{~m} 1 \mathrm{~m} 2-\mathrm{b} 2 \mathrm{~m} 1 \mathrm{~m} 2$.

These are all people who migrated into county one from another county and then migrated out again between 1930 and 1940 and so the term sums to zero. Thus, there is no bias in our method in comparison with adding up all of the in-migrants for the decade and subtracting all of the out-migrants for the decade. Thus, the net migration measure under either set of calculations becomes:

$\mathrm{NM} 13040=\mathrm{p} 1 \mathrm{~m} 2 \mathrm{~m} 1+\mathrm{b} 1 \mathrm{~m} 2 \mathrm{~m} 1+\mathrm{p} 2 \mathrm{~m} 1 \mathrm{~s} 1+\mathrm{b} 2 \mathrm{~m} 1 \mathrm{~s} 1+\mathrm{p} 2 \mathrm{~m} 1 \mathrm{~d} 1+\mathrm{b} 2 \mathrm{~m} 1 \mathrm{~d} 1$

-p1m2s2-p1m2m1-p1m2d2-b1m2s2-b1m2m1-b1m2d2. 
By further subtracting of like terms, the figure can be reduced further. Outmigration by people who started in the county in 1930 is offset by return inmigration of the same person before 1940 (p1m2m1p1m2m1). Outmigration by people born in the county after 1930 is offset by return inmigration of the same person before 1940 (b1m2m1-b1m2m1). Therefore,

$\mathrm{NM} 13040=\mathrm{p} 2 \mathrm{~m} 1 \mathrm{~s} 1+\mathrm{b} 2 \mathrm{~m} 1 \mathrm{~s} 1-\mathrm{p} 1 \mathrm{~m} 2 \mathrm{~s} 2-\mathrm{b} 1 \mathrm{~m} 2 \mathrm{~s} 2+\mathrm{p} 2 \mathrm{~m} 1 \mathrm{~d} 1+\mathrm{b} 2 \mathrm{~m} 1 \mathrm{~d} 1-\mathrm{p} 1 \mathrm{~m} 2 \mathrm{~d} 2-\mathrm{b} 1 \mathrm{~m} 2 \mathrm{~d} 2$

The first four terms in the net migration measure are in-migrants and out-migrants who moved to a county and stayed in that county through 1940 after migrating. The last four terms are in-migrants and outmigrants who moved to a county and then died in that county before 1940.

There is no bias if one is interested in adding up all immigrants and all outmigrants and finding the net number for the entire decade. There is a time aggregation problem in that people interested in the annual flows would get a better picture of all the movement in and out of the county each year. But our New Deal county data is aggregated across the decade, so this would do us no good for our analysis. There is a bias if people are interested in knowing the net number of people who migrated into or out of the county who were still alive somewhere in the U.S in 1940. The last four terms in the Net migration equation includes migrants who died before 1940. Since migrants tend to be younger, our sense is that this bias will not be large.

Now consider the census survival method used by Gardner and Cohen. They also net out all of the people who both inmigrated and outmigrated during the course of the decade. They have no information about the births and disposition of those born after 1930, although they developed an estimate in which they had little confidence. If you are interested in netting out all of the immigrants and outmigrants who came or went at any time in the decade, they will also miss all of the people who migrated into or out of the county and died before 1940.

Now consider the 1935-1940 census information. We know the location of the person in 1940 and 1935. Just like in the other two cases there is time aggregation bias because the people who moved in and out between the two dates cancel each other out. We also miss the people who move in and die prior to 1935 or move out and die elsewhere prior to 1935 . We also miss the people who are born between 
1935 and 1940 who moved in or moved out. This is the best measure if you want to know the netmigration over the period of all people alive in 1940. 


\section{FOOTNOTES}

${ }^{1}$ For recent treatments of this issue, see Hatton and Williamson (1998), Borjas (1999), and Ferrie (1999).

${ }^{2}$ For estimates of the impact of modern welfare benefit levels on migration decisions across states, see Gramlich and Laren (1984), Blank (1988), and Moffit (1992), Allard and Danziger 2000, and Levine and Zimmerman (1999). Kauffman and Kiesling (1999) did study welfare benefits within the states but only focused on Brooklyn and Manhattan.

${ }^{3}$ During downturns, migration tends to be reduced. Overall, the 1930s internal migration was less for most states then in other decades between 1900 and 1970. As seen in the text the extent of movement in the 1930s was still substantial. See U.S. Bureau of the Census (1975, p. 93)

${ }^{4}$ Bogue, Shyrock, and Hoerman (1957) analyzed 1930s migration trends using census information reporting the location of individuals in 1935 and 1940. They found shifts from rural to urban areas; from central cities to suburbs; shifts westward, particularly from the Midwest; a shift of the black population from the South into the North; and substantial movement by white collar and educated workers. Their empirical analysis, however, said very little about the New Deal and how the various programs might have influenced migration.

${ }^{5}$ See the notes to series c25-c27 in U.S. Bureau of the Census (1975) for a discussion of the components of change method and estimates at the state level using the method for the 1940s, 1950s, and 1960s. ${ }^{6}$ Given that the Census is usually taken in the middle of the year, we based our calculations of the natural increase between 1930 and 1940 using half of 1930's and 1940's data. That is, we used half of the births, deaths, and infant deaths in 1930 and half in 1940. Texas and South Dakota were the last states to start reporting the information for all of their counties in 1933. To get estimates for the 10 -year period, we multiplied the natural increases in the counties in these states for 1933 through 1940 by 1.25 .

${ }^{7}$ Using alternative techniques Gardner and Cohen also developed a rough estimate of net migration for the age group under 10. The correlation between their measure of net migration using all age groups and using just those 10 and over is .995 . Given that Gardner and Cohen express reservations about the 
inclusion of the 0-9 age group, we make comparisons of our estimates with their estimates for ages 10 and over.

${ }^{8}$ Comparisons of the three methods of calculations for net migration led to the following conclusions. First, for scholars interested in annual net migration there is a time aggregation bias problem for all three because all three methods miss people who both migrate in and migrate out of the county between the beginning and ending dates (and vice versa). This aggregation problem can only be solved with data for shorter time periods. Second, our method takes into account migration by people born after the starting date of the period, while the 1935-1940 Census and Gardner and Cohen methods do not (although Gardner and Cohen developed some estimate of births during the period that they do not have much confidence in). Third, our method includes people as net in-migrants who migrate into a county and then die before 1940 and out-migrants who move to another county and die before 1940. Neither the Census 1935-1940 information nor the Gardner and Cohen survival method includes these migrants. Thus, there may be a bias if people are interested in the number of net-migrants in a county who are still alive in 1940. Since migrants tend to be younger with lower death rates, we believe this will not be a serious bias. To the extent that the deaths of immigrants in a county are greater (less) than the deaths of outmigrants from the county, we will overstate (understate) the number of immigrants who were still there in 1940. ${ }^{8}$ We are in the middle of analyzing the 1935-1940 household migration data from the IPUMS, where we can use data on New Deal spending for over 450 state economic areas (SEA), as counties are not reported. We ran a preliminary logit regression on 250,000 household head's decisions to switch SEAs as a function of economic activity and the New Deal variables in the household head's location as of 1940, some individual characteristics like age and education, and state dummies. The results are similar to our county-level results in this paper. People are more likely to have moved from an SEA in 1935 to the current SEA in 1940 when the 1940 location had higher spending on public works and relief throughout the 1930s and the effect is statistically significant. The AAA effect is negative although not statistically significant. 
${ }^{9}$ We are in the middle of analyzing the 1935-1940 household data, where we can use data on New Deal spending for over 450 state economic areas (SEA), as counties are not reported. We ran a preliminary logit regression on 250,000 household head's decisions to switch SEAs as a function of economic activity and the New Deal variables in the household head's location as of 1940, some individual characteristics like age and education, and state dummies. The results are similar to our county-level results in this paper. People are more likely to have moved from an SEA in 1935 to the current SEA in 1940 when the 1940 location had higher spending on public works and relief throughout the 1930s and the effect is statistically significant. The AAA effect is negative although not statistically significant.

${ }^{10}$ The Office of Government Reports also provided information on $\$ 10.4$ billion in repayable loans under a variety of programs. Meanwhile, the Federal Housing Administration insured \$2.7 billion in mortgage loans. We do not focus on these programs in this paper for several reasons. First, the nature of the loans and insurance were substantially different from the nonrepayable grants and it is hard to determine the true dollar size of the benefits from the loans and the FHA insurance. A substantial portion of the loans were repaid within a relatively short period of time and the grant feature of the loans would have come in the form of favorable interest rates given the risk of repayment and favorable repayment terms. The OGR did not provide information on these features, so we have no direct means of estimating the true size of the federal subsidy. Under the FHA program banks approached the FHA for insurance once they had decided to write a mortgage contract that would have satisfied FHA criteria. The federal government's outlays for this program were very small relative to the value of the loans because the FHA was careful in choosing the loans to insure and consequently paid out less than 1 percent of loan value in insurance claims. Second, in the analysis we seek to reduce problems of endogeneity by using instrumental variables. We face difficulties in finding enough effective instruments that will allow us to simultaneously identify more than two or three New Deal variables in a system of equations. In our attempts to use our group of instruments to simultaneously identify equations where the FHA and loans are included along with the grants as endogenous variables, the 2SLS results contain no statistically 
significant effects for any variables, which is a sign that the instruments are too weak to identify the system. Third, by omitting the loans and FHA insurance we reduce measurement error at the risk of increasing omitted variables bias in our estimates of the impact of New Deal grants. We do not believe that the bias will be large from omitting the loans and FHA insured loans because these variables are largely orthogonal to the grants variable. When we examine the AAA grants and the public works and relief grants separately, we do not anticipate much bias for the public works and relief grants coefficient because the correlations with farm loans, nonfarm loans and FHA insured loans are .06, .03 and 0.15, respectively. The AAA grant spending is largely uncorrelated with nonfarm loans and FHA insured loans at -.07 and -.14, respectively. However, the AAA grant spending may be picking up some of the impact of farm loans, because the correlation is high at .75 and Fishback, Kantor, and Wallis find that the determinants of the geographic distribution of farm loans and AAA grants had similar effects.

${ }^{11}$ See Fishback, Kantor, and Wallis (2003) for a table that summarizes the various studies of the distribution of New Deal funds. Couch, Atkinson, and Wells (1999) and Couch and Williams (1998) have used Alabama counties to examine the distribution of New Deal agricultural and total funds. Using another data source, Fleck (1999b, 2001a) has used county-level data to examine the distribution of relief and its impact on unemployment.

${ }^{12}$ New Deal spending did not represent all federal spending, so our analysis does not address the impact of all forms of federal expenditures. It should be noted, however, that much of the New Deal represented an entirely new role for the federal government. For example, agricultural spending, relief spending, many forms of lending to state and local governments, and insurance of mortgage loans broke new ground for the federal government. In addition, there were major increases in federal spending from the early 1930s on roads, public buildings, public works, and conservation. The New Deal programs caused federal intergovernmental and direct outlays on education to rise from 26 million in 1932 to 235 million in 1934, on highways from 217 million to 599 million, on public welfare and employment security from 2 million to 585 million, on housing and urban renewal from 0 in 1932 to 3 million in 1934 to 71 in 1936. 
Federal outlays on the pre-1930 primary tasks of the federal government generally did not display the same marked jumps. See Wallis 1985 and U.S. Bureau of Census 1975, pp. 1124-26.

${ }^{13}$ The Civilian Conservation Corps often moved young men across states, but we do not have county level information on the CCC and, thus, cannot measure its impact in this study.

${ }^{14}$ We have been unable to create a good measure of net migration by county for the 1920 s for the entire country. A number of states did not join the birth and death registration areas until sometime during the 1920s, leading to large numbers of missing values. Nor can we use the Gardner and Cohen technique because the 1920 census does not report the age/race/sex breakdowns by county necessary to perform their calculations.

${ }^{15}$ Of particular interest is the relationship between net migration and economic activity. Since migration is based less on past conditions, but on expectations about the future, we have also experimented with recasting the analysis using a measure of average retail sales per capita for the 1930s as a measure of future economic opportunities in an area. We use it as a proxy for personal income, which the Census did not report at the county level in 1940. Including average retail sales per capita for the years 1933, 1935, and 1939 in place of the 1929 value leads to a coefficient that is nearly double the coefficient reported in Tables 3 and 5. However, there is the possibility of endogeneity bias if in-flows of migrants raised per capita retail sales spending because of agglomeration, for example. When we treat the 1930s retail sales as an endogenous variable and use retail sales in 1929 as an instrument in the 2SLS analysis, the coefficient lies somewhere between the coefficient when we use the 1929 values as the proxy for income and the coefficient when we treat the 1930s retail sales as exogenous. We have also explored using logged values of retail sales per capita and population and find the same statistically significant signs for their effects on net migration. Inclusion of each of these the alternative measures of retail sales per capita have little effect on the New Deal coefficients and t-statistics.

${ }^{16}$ We have explored using alternative income estimates, like average annual earnings per manufacturing employee or average crop output per person on farms. Two major problems arise when we try to use 
these alternatives. First, there are substantial missing data for manufacturing earnings, causing us to lose over 600 observations. Second, creating a measure that combines both manufacturing and farm income into a single index is difficult because they are quite distinct.

We have also explored developing an interpolated measure of per capita personal income at the county level by using predictions from a cross-state regression of per capita personal income on per capita retail sales and percent urban. The predicted personal income at the county level was so closely correlated with retail sales (.95) that we felt it was better to explicitly use retail sales as our measure of economic activity to avoid misleading the reader about the source of the variation in the economic activity variable.

${ }^{17}$ For discussions of the determinants of New Deal spending, see Reading 1973; Wright 1974; Wallis 1987, 1998, and 2001; Anderson and Tollison 1991; Couch and Shughart 1998; Couch, Atkinson, and Wells, 1998; Fleck 1999a, 1999b, 2001a, 2001b; Couch and Williams 1999; and Fishback, Kantor, and Wallis 2003. The last paper summarizes the results of all of the studies and provides new estimates. ${ }^{18}$ Fleck's (2001a, 2001b, 2001c) county-level research finds that swing voters were important determinants of the number of relief jobs allocated to a county and the standard deviation could be used as an instrument for relief in a 2SLS county unemployment rate analysis. He has also explored more complicated interactions of swing voting with voter loyalty. In response to suggestions that we explore differential effects for the standard deviation on the New Deal distribution related to urbanization, region, and Democratic loyalty, we have also tried adding interactions between a southern region dummy, percent urban, and a Democratic loyalty variable to the list of identifying instruments. Their inclusion as instruments leads to the same qualitative conclusions about the effects of the New Deal, but sharply reduces the F-statistic for the hypothesis test that the coefficients of the identifying instruments are all zero. Another suggestion was to use state capitals as an instrument, but it had little effect on the New Deal variables. When included in the final net migration equation, its positive effect varied from specification in terms of its statistical significance. 
${ }^{19}$ As one example, Caroline Hoxby (2000) used the number of streams in an area as an instrument for the number of school districts on the grounds that they were natural boundaries that would have influenced the location of school district boundaries. As seen in the text, we use major rivers for different reasons. ${ }^{20}$ In 1,763 counties the value for each major river variable was zero. The maximum number of major rivers within a county was two for the rivers passing through 11 to 20 total counties, three for the rivers passing through 21 to 50 total counties, and 2 for the largest rivers. Summing the total major rivers across all three categories, the maximum in any one county was 4 . We control for the possibility that bigger counties would have had more rivers by including county land area in the analysis. We also experimented with a variable measuring the number of rivers in a county passing through 5 to 10 total counties, but the coefficients in the first-stage regressions were always small and statistically insignificant ${ }^{21}$ According to the U.S. Natural Resources Conservation Service, AWC is "the volume of water released from the soil between the time the soil is at field capacity (the maximum water held in soil against the pull of gravity) until the time it is at the wilting point (the amount of water held too tightly in soil for commonly grown crops to extract). Loamy soils and soils high in organic matter have the highest AWC." See http://soils.usda.gov/sqi/soil_quality/what_is/glossary.html. We have also experimented with using other dimensions of soil quality, including clay content, k-factor measures of soil loss due to water, the liquid limit of the soil, organic matter, permeability of the soil, soil depth, a measure of hydrologic characteristics, drainage, slope, hydric nature of the soils, and annual flood frequency. None display as strong an effect on AAA spending or public works spending as the AWC in the first stage. When we include these other characteristics as exogenous variables in both the first and second stages, we continue to find strong positive effects of public works and relief on net migration and strong negative effects of the AAA.

${ }^{22}$ The negative sign makes sense if water and soil quality can be seen as substitutes in production, such that better water soil quality requires less in the way of irrigation projects. 
${ }^{23}$ We have also explored the possibility of including spillover effects for the endogenous New Deal spending variables. Our initial results suggested that the weighted values of the New Deal variables in neighboring counties out to 100 miles were small and statistically insignificant. There was also a substantial reduction in the public works and relief coefficient for spending in county $i$, but little change in the AAA coefficient. One problem that arises when we seek to include the neighboring New Deal variables is that we are including neighbor-weighted endogenous variables. This requires an expansion in the number of instruments. The Kelejian-Prucha solution to this problem is to add neighbor-weighted averages for all of the exogenous variables in G2SLS system, which leads to a very large number of identifying instruments. Closer inspection shows that the change in results for the relief/public works coefficient is driven not by the inclusion of the neighbor weighted New Deal variables, but instead by the addition of the large number of new identifying instruments. When we estimate the model with the expanded list of neighbor-weighted instruments without including the neighbors New Deal spending in the final model, we see the same change in the public works and relief coefficient. It turns out that it is the addition of these additional instruments and not the inclusion of the New Deal spending in nearby counties that is causing the sharp change in the public works spending coefficient. In essence, the Kelejian-Prucha method leads us into a situation identified by Bound, Jaeger, and Baker (1995) where the inclusion of a large number of instruments, many of which are unrelated to the endogenous variable, creates a substantial problem with weak instrument bias, a finding corroborated in our data using a HahnHausman (2002) test.

${ }^{24}$ At a cut-off of 100 radial miles the median number of "neighbors" is 44 counties, with a maximum of 102 neighbors and a minimum of 1 . The distribution of neighbors at a cut-off of 200 miles was 168 median neighbors, with a maximum of 328 and a minimum of 7 . At 600 miles, the distribution was less symmetric with most of the probability weight in the right tail of the distribution (1,157 median neighbors, 1,855 maximum, and 104 minimum neighbors).

${ }^{25}$ An empirical artifact of these data is that as $d^{*}$ increases, the magnitude of our estimate $\rho$ increases. 
${ }^{26}$ We have also estimated the basic 2 SLS model in which the errors are clustered at the state level. Our tstatistics are in the same ranges as those reported here. Our use of the distance-based spatial weighting allows for differential weighting of nearby counties and the G2SLS procedure allows us to explicitly test for the effect of neighbors' incomes.

${ }^{27}$ In the analysis the coefficients of unemployment measures in 1930 both are negative but are statistically insignificant. There are two additional measures at the county level that might be used as a sign of unemployment during the 1930s - the FERA (1934) survey of the number of people on relief as of October 1933 and the Census of Partial Employment, Unemployment, and Occupations (1938) postal survey of the totally and partially unemployed in November 1937. The latter was a voluntary census through which people filled out registration cards and returned them to their postal worker. When the Census checked the postal census with an enumeration census, they found that nearly all workers on emergency projects (the WPA) had filled out cards, but that 35 percent of the totally unemployed were left uncounted and 42 percent of the partially unemployed were left uncounted. We have experimented with including the number on relief in 1933 and found that the number on relief was associated with outmigration but the coefficient was statistically insignificant. Of course, this measure serves also as a measure of availability of relief, so the small effect would not be surprising. When we include the percentages of totally and partially unemployed (leaving out emergency workers) in 1937, we get a statistically significant and strong relationship between both measures and out-migration. This effect might be overstated to the extent that out-migration reduced unemployment problems. The inclusion of these alternative estimates of unemployment variables has little effect on the New Deal coefficients and tstatistics.

${ }^{28}$ By 1940 the percentage of men aged 65 and over in the labor force had fallen to 50 percent, and a significant proportion of those considered themselves retired. See Costa 1998, chapter 1.

${ }^{29}$ We have explored using deviations in the climate variables during the 1930s from their long-term trends, 1894 through 1929. When the deviations are included in the analysis either alone or in 
combination with the level information that we report in the text, they appear to have little impact on net migration.

${ }^{30}$ See U. S. Bureau of Census, Historical Statistics, pp. 211-12, series E-135.

${ }^{31}$ We made several corrections to the Sechrist data set, which are reported in Fishback, Horrace, and Kantor (2004, Appendix 1).

${ }^{32}$ See Fishback, Horrace, and Kantor (2004, Appendix 1) for a more complete discussion of the creation of the geography variables and of our handling of county boundary changes since the New Deal.

${ }^{33}$ For an extensive discussion of the procedures for estimating migration using the census survival method, as well as additional estimates of net migration at the state level, see Lee (1957). 


\section{REFERENCES}

Allard, Scott and Sheldon Danziger. "Welfare Magnets: Myth or Reality?" The Journal of Politics 62 (May 2000): 350-368.

Alston, Lee J., "Tenure Choice in Southern Agriculture, 1930-1960," Explorations in Economic History, 18 (July 1981), 211-32.

Anderson, Gary M., and Robert D. Tollison, "Congressional Influence and Patterns of New Deal Spending, 1933-1939," Journal of Law and Economics, 34 (April 1991), 161-75.

Arrington, Leonard, "Western Agriculture and the New Deal," Agricultural History, 49 (Oct. 1970), 33753.

Attfield, C.L.F., E.S. Cannon, D. Demery and W.D. Nigel, "Economic Growth and Geographic Proximity," Economic Letters, 68 (July 2000), 109-12.

Biles, Roger, The South and the New Deal (Lexington, KY: University of Kentucky Press, 1994).

Blank, Rebecca, "The Effect of Welfare and Wage Levels on the Location Decisions of Female-Headed Households," Journal of Urban Economics, 24 (Sept. 1998) 186-211.

Bogue, Donald J, Henry S. Shyrock, Jr., and Siegried A. Hoermann, Subregional Migration in the United States, 1935-40 Volume I Streams of Migration Between Subregions (Oxford, Ohio: Scripps Foundation, 1957).

Borjas, George J., Heaven's Door: Immigration Policy and the American Economy (Princeton, NJ: Princeton University Press, 1999).

Bound, John, David Jaeger and Regina M. Baker. "Problems with Instrumental Variables Estimation When the Correlation Between the Instruments and the Endogenous Explanatory Variables is Weak." Journal of the American Statistical Association 90 (June 1995): 443-450.

Brown, Josephine Chapin, Public Relief, 1929-1939 (New York: Henry Holt and Company, 1940).

Census of Partial Employment, Unemployment, and Occupations. Final Report on Total and Partial Unemployment, 1937. 4 volumes. (Washington, DC: GPO, 1938).

Clarke, Jeanne Nienaber, Roosevelt's Warrior: Harold L. Ickes and the New Deal (Baltimore: Johns Hopkins University Press, 1996).

Couch, Jim, Atkinson, Keith E.; Wells, William H., "New Deal Agricultural Appropriations: A Political Influence. Eastern Economic Journal 24 (Spring 1998): 137-48.

Couch, Jim, and William Shughart II, The Political Economy of the New Deal (New York: Edward Elgar, 1998).

Couch Jim and Peter M. Williams. "New Deal or Same Old Shuffle? The Distribution of New Deal Dollars Across Alabama," Economics and Politics 11 (July 1999): 213-223.

Darby, Michael R., "Three-and-a-Half Million U.S. Employees Have Been Mislaid: Or, an Explanation of Unemployment, 1934-1941," Journal of Political Economy, 84 (Feb. 1976), 1-16.

Dowd, Michael R., and James P. LeSage, "Analysis of Spatial Contiguity Influences on State Price Level Information," International Journal of Forecasting, 13 (June 1997), 245-53.

Federal Emergency Relief Administration. Unemployment Relief Census, October 1933. 2 Reports. (Washington, D.C.: Government Printing Office, 1934.)

Federal Housing Administration, Annual Report (Washington, DC: GPO, various years).

Federal Works Agency, Work Projects Administration, Final Statistical Report of the Federal Emergency Relief Administration (Washington, DC: GPO, 1942).

Ferrie, Joseph P., Yankeys Now: Immigrants in the Antebellum U.S., 1840-1860 (New York: Oxford University Press, 1999).

Fishback, Price V., Michael R. Haines, and Shawn Kantor, "The Welfare of Children During the Great Depression," National Bureau of Economic Research Working Paper 8902, revised October 2003.

Fishback, Price V., William C. Horrace, and Shawn Kantor, "Did New Deal Grant Programs Stimulate Local Economies? A Study of Federal Grants and Retail Sales During the Great Depression," Journal of Economic History, forthcoming March 2005. 
. "Do Federal Programs Affect Internal Migration? The Impact of New Deal Expenditures on Mobility During the Great Depression." NBER Working Paper No. w8283, revised and updated 2005.

, "Federal Programs in Times of Crisis: The Impact of the New Deal on Local Economies During the Great Depression," National Bureau of Economic Research Working Paper 8108, revised March 2004.

Fishback, Price V., Shawn Kantor, and John Joseph Wallis, "Can the New Deal's Three Rs Be Rehabilitated? A Program-by-Program, County-by-County Analysis," Explorations in Economic History, 40 (July 2003), 278-307

Fleck, Robert Kenneth, "Essays on the Political Economy of the New Deal," unpublished Ph.D. dissertation, Stanford University, 1994.

"Inter-party competition, intra-party competition, and distributive Policy: A Model and Test Using New Deal Data." Public Choice 108 (2001a): 77-100.

"The Marginal Effect of New Deal Relief Work on County-Level Unemployment Statistics." Journal of Economic History 59 (September 1999a), 659-87.

"Population, Land, Economic Conditions, and the Allocation of New Deal Spending." Explorations in Economic History 38 (2001b): 296-304.

"The Value of the Vote: A Model and Test of the Effects of Turnout on Distributive Policy," Economic Inquiry 37 (October 1999b): 609-23.

Frankel, Jeffrey A., and David Romer, "Does Trade Cause Growth?" American Economic Review 89 (June 1999), 379-99.

Gardner, John, and William Cohen, "Demographic Characteristics of the Population of the United States, 1930-1950: County-Level," ICPSR file 0020, 1992.

Gramlich, Edward, and Deborah Laren "Migration and Income Redistribution Responsibilities,” Journal of Human Resources, 19 (Fall 1984), 489-511.

Greene, William H. Econometric Analysis, fifth Edition. New York: Prentice Hall, 2003.

Greenwood, Michael J., "Research on Internal Migration in the United States: A Survey," Journal of Economic Literature 13 (June 1975), 397-433.

, "Human Migration: Theory, Models, and Empirical Studies," Journal of Regional Science, 25 (1985), 521-44.

Hahn, Jinyong, and Jerry Hausman. "A New Specification Test for the Validity of Instrumental Variables." Econometrica 70, no. 1 (2002): 163-89.

Hansen, Zeynep and Gary Libecap. "Small Farms, Externalities, and the Dust Bowl of the 1930s." Journal of Political Economy 112 (June 2004): 665-694.

Hatton, T. J., and Jeffrey G. Williamson, The Age of Mass Migration: Causes and Economic Impact (New York: Oxford University Press, 1998).

Hausman, Jerry. "Specification and Estimation of Simultaneous Models." In Handbook of Econometrics, edited by Zvi Griliches and Michael Intrilligator, 391-448. Amsterdam: NorthHolland, 1983.

Hines, James R. Jr., and Richard H. Thaler, “The Flypaper Effect,” Journal of Economic Perspectives, 9 (Fall 1995), 217-26.

Holley, William C., Ellen Winston, and Thomas Jackson Woofter. The Plantation South, 1934-1937. Freeport, NY, Books for Library Press, 1971 (reprint of 1940 edition).

Howard, Donald S., The WPA and Federal Relief Policy (New York: Russell Sage Foundation, 1943).

Hoxby, Caroline M., "Does Competition Among Public Schools Benefit Students and Taxpayers?," American Economic Review, 90 (De. 2000), 1209-38.

Inter-University Consortium for Political and Social Research, Historical, Demographic, Economic, and Social Data: The United States, 1790-1970, ICPSR Number 0003. Computerized data tapes from ICPSR. The version has corrections by Michael Haines, Department of Economics, Colgate University, Hamilton, NY.

Inter-University Consortium for Political and Social Research, United States Historical Election Returns, 
1824-1968, ICPSR Number 0001. Computerized data tapes from ICPSR.

Jones, Jesse H, Reconstruction Finance Corporation Seven-Year Report to the President and the Congress of the United States, February 2, 1932 to February 2, 1939, Reconstruction Finance Corporation pamphlet, 1939.

Lee, Everett, "Migration Estimates," in Simon Kuznets and Dorothy Swaine Thomas, ed., Population Redistribution and Economic Growth, United States, 1870-1950, Volume I (Philadelphia: The American Philosophical Society, 1957).

Kauffman, Kyle and Lynne Kiesling. "Was There a Nineteenth Century Welfare Magnet in the United States? Preliminary Results from New York City and Brooklyn." The Quarterly Review of Economics and Finance 37 (Summer 1997): 439-448.

Kelejian, Harry H., Two-Stage Least Squares and Econometric Systems Linear in Parameters But Nonlinear in Endogenous Variables," Journal of the American Statistical Association, 66 (June 1971), 373-74.

Kelejian, Harry H., and Ingmar R. Prucha, "A Generalized Moments Estimator for the Autoregressive Parameter in a Spatial Model,” International Economic Review, 40 (May 1999), 509-33. "Estimation of Simultaneous Systems of Spatially Interelated Cross Sectional Equations," Unpublished manuscript, University of Maryland, 1998.

Kelejian, Harry H., and Dennis P. Robinson, "A Suggested Method of Estimation for Spatial Interdependent Models with Autocorrelated Errors, and an Application to a County Expenditure Model," Papers in Regional Science, 72 (no. 3, 1993), 297-312.

Levine, Phillip and David Zimmerman. "An Empirical Analysis of the Welfare Magnet Debate Using the NLSY." Journal of Population Economics 12 (1999): 391-409.

Mertz, Paul E. New Deal Policy and Southern Rural Poverty. Baton Rouge, LA, Louisiana State University Press, 1978.

Moffitt, Robert, "Incentive Effects of the U.S. Welfare System: A Review," Journal of Economic Literature, 30 (Mar. 1992), 1-61.

Oates, Wallace, Fiscal Federalism (New York: Harcourt Brace Jovanich,1973).

Olson, James S., Saving Capitalism: The Reconstruction Finance Corporation and the New Deal, 19331940 (Princeton, NJ: Princeton University Press, 1988).

Petree, John. "Report of the Functions of theVarious Federal Emergency Agencies for Alabama, December 13, 1934" from Periodical Reports of State Directors, 1934-1938. Office of Government Reports, Record Group 44, National Archives, Entry 29, Box 392. 1934.

Reading, Don C., "New Deal Activity and the States, 1933 to 1939," Journal of Economic History, 33 (Dec. 1973), 792-810.

Romer, Christina D., "Why Did Prices Rise in the 1930s?" Journal of Economic History, 59 (March 1999), 167-99.

Saloutos, Theodore, "New Deal Agricultural Policy: An Evaluation," Journal of American History 61 (Sept. 1974), 394-416.

Schmidt, Peter, Econometrics (New York: Dekker, 1976).

Schwartz, Aba, "Interpreting the Effect of Distance on Migration," Journal of Political Economy, 81 (Sept./Oct. 1973), 1153-69.

Sechrist, Robert P. Basic Geographic and Historic Data for Interfacing ICPSR Data Sets, 1620-1983 (United States). Inter-university Consortium for Political and Social Research, Spring 1984.

Schlesinger, Arthur, The Age of Roosevelt: The Coming of the New Deal (Boston: Houghton-Mifflin, 1958).

U.S. Bureau of the Census, Birth, Stillbirth, and Infant Mortality Statistics for the Birth Registration Area of the United States, 1930, Sixteenth Annual Report (Washington, DC: GPO, 1934a).

U.S. Bureau of the Census, Birth, Stillbirth, and Infant Mortality Statistics for the Birth Registration Area of the United States, 1931, Seventeenth Annual Report (Washington, DC: GPO, 1934b).

U.S. Bureau of the Census, Birth, Stillbirth, and Infant Mortality Statistics for the Birth Registration Area of the United States, 1932, Eighteenth Annual Report (Washington, DC: GPO, 1934c). 
U.S. Bureau of the Census, Birth, Stillbirth, and Infant Mortality Statistics for the Continental United States, The Territory of Hawaii, and the Virgin Islands, 1933, Nineteenth First Annual Report (Washington, DC: GPO, 1936a).

U.S. Bureau of the Census, Birth, Stillbirth, and Infant Mortality Statistics for the Continental United States, The Territory of Hawaii, and the Virgin Islands, 1934, Twentieth Annual Report (Washington, DC: GPO, 1936b).

U.S. Bureau of the Census, Birth, Stillbirth, and Infant Mortality Statistics for the Continental United States, The Territory of Hawaii, and the Virgin Islands, 1935, Twenty-First Annual Report (Washington, DC: GPO, 1937).

U.S. Bureau of the Census, Birth, Stillbirth, and Infant Mortality Statistics for the Continental United States, The Territory of Hawaii, and the Virgin Islands, 1936, Twenty-Second Annual Report (Washington, DC: GPO, 1938).

U.S. Bureau of the Census, Birth, Stillbirth, and Infant Mortality Statistics for the Continental United States, The Territory of Hawaii, and the Virgin Islands, 1937, Twenty-Third Annual Report (Washington, DC: GPO, 1939).

U.S. Bureau of the Census, Birth, Stillbirth, and Infant Mortality Statistics for the Continental United States, The Territory of Hawaii, and the Virgin Islands, 1938, Twenty-Fourth Annual Report (Washington, DC: GPO, 1940).

U.S. Bureau of the Census, Birth, Stillbirth, and Infant Mortality Statistics for the Continental United

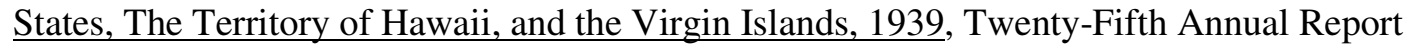
(Washington, DC: GPO, 1941).

U.S. Bureau of the Census, Birth, Stillbirth, and Infant Mortality Statistics for the Continental United States, The Territory of Hawaii, and the Virgin Islands, 1940, Twenty-Sixth Annual Report (Washington, DC: GPO, 1942).

U.S. Bureau of the Census, "Completeness of Birth Registration in Urban and Rural Areas, United States and Each State, December 1, 1939 to March 31, 1940," Vital Statistics - Special Reports, Selected Studies. Volume 23, Number 6. November 2, 1945.

U.S. Bureau of the Census. Fifteenth Census of the United States, 1930, Population, Volume VI: Families. Washington, D.C.: Government Printing Office, 1933.

U.S. Bureau of the Census. Financial Statistics of State and Local Governments: 1932. Washington, D.C.: Government Printing Office, 1935.

U.S. Bureau of the Census, Historical Statistics of the United States: Colonial Times to 1970 (Washington, DC: GPO, 1975).

U.S. Bureau of the Census, "Illiteracy in the United States, October 1947," Current Population Reports: Population Characteristics, Series P-20 no. 20, September 22, 1948.

U.S. Bureau of the Census, Religious Bodies: 1926, Volume 1. Washington, D.C.: Government Printing Office, 1930.

U.S. Bureau of the Census, Sixteenth Census of the United States, 1940: Population, Internal Migration, 1935 to 1940 (Washington, DC: GPO, 1943).

U.S. Congress, Official Congressional Directory, for the $73^{\text {rd }}$ Congress $1^{\text {st }}$ session through $76^{\text {th }}$ Congress (Washington, D.C.: GPO, various years).

U.S. Department of Commerce, Bureau of Foreign and Domestic Commerce, Consumer Market Data Handbook. (Washington, D.C.: GPO, 1936).

U.S. Department of Commerce, Bureau of Foreign and Domestic Commerce, Consumer Market Data Handbook. (Washington, D.C.: GPO, 1939).

U.S. Department of Commerce, Bureau of Foreign and Domestic Commerce, General Consumer Market Statistics, Supplement 1 to the Market Data Handbook of the United States. (Washington, D.C.: GPO, 1932).

U.S. Farm Credit Administration, Financing Agriculture in 1934 (Washington, D.C: GPO, 1935). , Farm Credit Quarterly, June 1936 (Washington, D.C.: GPO, 1936). 
U.S. Federal Security Agency, United States Public Health Service, "Estimated Completeness of Birth Registration, United States, 1935 to 1944," Vital Statistics - Special Reports. Volume 23, Number 10. December 30, 1946.

U.S. Office of Government Reports, Statistical Section, Report No. 9, Volume 1, "Direct and Cooperative Loans and Expenditures of the Federal Government for Fiscal Years 1933 through 1939." Mimeo, 1940.

U.S. Office of Government Reports, Statistical Section, Report No. 10, Volume 1, "County Reports of Estimated Federal Expenditures March 4 1933-June 30, 1939,” Mimeo, 1940.

U.S. Senate, Expenditure of Funds Emergency Relief Administration: Letter from the Administrator of the Federal Emergency Relief Administration. Senate Document No. 56. $74^{\text {th }}$ Congress $1^{\text {st }}$ Session, Washington: GPO, 1935.

Wallis, John Joseph, “The Birth of the Old Federalism: Financing the New Deal, 1932-1940," Journal of Economic History, 44 (Mar. 1984), 139-59.

, "Why 1933? The Origins and Timing of National Government Growth, 1933-1940," Research in Economic History, 4 (1985), 1-51.

, "Employment, Politics, and Economic Recovery During the Great Depression," Review of Economics and Statistics, 69 (Aug. 1987), 516-20.

,"The Political Economy of New Deal Spending Revisited, Again: With and Without Nevada," Explorations in Economic History 35 (April 1998), 140-70.

"The Political Economy of New Deal Spending, Yet Again: A Reply," Explorations in Economic History 38 (April 2001): 305-14.

Wallis, John Joseph, and Daniel K. Benjamin, "Public Relief and Private Employment in the Great Depression," Journal of Economic History, 41 (Mar. 1981), 97-102.

, "Private Employment and Public Relief During the Great Depression," Department of Economics, University of Maryland working paper, 1989.

Webb, John N, "The Transient Unemployed," Monthly Report of the Federal Emergency Relief Administration, January 1 through January 31, 1936 (Washington, DC: GPO, 1936), 1-25.

Whatley, Warren C., "Labor for the Picking: The New Deal in the South," Journal of Economic History, 43 (Dec. 1983), 905-29.

Whelpton, P.K., "The Completeness of Birth Registration in the United States," Journal of the American Statistical Association, 26 (June 1934), 125-36.

Williams, Edward Ainsworth, Federal Aid for Relief (New York: AMS Press, reprint, 1968).

Wright, Gavin, "The Political Economy of New Deal Spending: An Econometric Analysis," Review of Economics and Statistics, 56 (Feb. 1974), 30-38. 


\section{Table 1}

Estimates of Net Migration Rates per 1,000 Population, 1930-1940, and Cumulative New Deal Spending by Purpose, 1933 to 1939

\begin{tabular}{|c|c|c|c|c|c|c|}
\hline \multirow[b]{2}{*}{ State } & \multirow[b]{2}{*}{$\begin{array}{l}\text { Population, } \\
1930\end{array}$} & \multicolumn{3}{|c|}{ Net Migration Measures } & \multicolumn{2}{|c|}{$\begin{array}{l}\text { Cumulative Per } \\
\text { Capita New Deal } \\
\text { Spending on: }\end{array}$} \\
\hline & & $\begin{array}{l}\text { Fishback, } \\
\text { Horrace, } \\
\text { \& } \\
\text { Kantor }\end{array}$ & $\begin{array}{l}\text { Gardner } \\
\text { \& } \\
\text { Cohen }\end{array}$ & $\begin{array}{l}\text { Estimate } \\
\text { based on } \\
\text { Census } \\
\text { measures } \\
\text { of } 1940 \\
\text { immigrants } \\
\text { minus } 1935 \\
\text { emigrants }^{\mathrm{a}} \\
\end{array}$ & $\begin{array}{l}\text { Public } \\
\text { Works } \\
\text { and Relief } \\
\text { Grants }\end{array}$ & $\begin{array}{l}\text { AAA } \\
\text { Grants }\end{array}$ \\
\hline \multicolumn{7}{|l|}{ NEW ENGLAND } \\
\hline Connecticut & $1,606,903$ & 31.1 & 23.6 & 31.0 & $\$ 91.60$ & $\$ 2.10$ \\
\hline Maine & 797,423 & 8.9 & -2.1 & -21.6 & 102.40 & 1.5 \\
\hline Massachusetts & $4,249,614$ & -11 & -17 & -15.2 & 130.40 & 0.5 \\
\hline New Hampshire & 465,293 & 29.1 & 18.7 & 26.3 & 85.90 & 0.8 \\
\hline Rhode Island & 687,497 & 3.9 & -4 & 1.2 & 104.90 & 0.1 \\
\hline $\begin{array}{l}\text { Vermont } \\
\text { MID-ATLANTIC }\end{array}$ & 359,611 & -49.4 & -52.5 & -31.9 & 76.20 & 2.4 \\
\hline Delaware & 238,380 & 86.9 & 66.8 & 86.6 & 111.10 & 5.6 \\
\hline New Jersey & $4,041,334$ & 0.6 & -7.4 & 14.5 & 125.00 & 0.5 \\
\hline New York & $12,588,066$ & 43.9 & 31.1 & -9.1 & 150.50 & 0.6 \\
\hline Pennsylvania & $9,631,350$ & -24.3 & -31.5 & -21.5 & 134.70 & 1.1 \\
\hline \multicolumn{7}{|l|}{$\begin{array}{l}\text { EAST NORTH } \\
\text { CENTRAL }\end{array}$} \\
\hline Illinois & $7,630,654$ & -2 & -8.4 & -5.0 & 133.30 & 12.7 \\
\hline Indiana & $3,238,503$ & 10.9 & 3.1 & 16.2 & 115.80 & 18.7 \\
\hline Michigan & $4,842,325$ & 11 & 3.3 & 31.4 & 116.20 & 5 \\
\hline Ohio & $6,646,697$ & -3.8 & -8.7 & -2.9 & 140.20 & 7.5 \\
\hline Wisconsin & $2,939,006$ & -7.7 & -4.3 & -21.6 & 126.80 & 11.5 \\
\hline \multicolumn{7}{|l|}{$\begin{array}{l}\text { WEST NORTH } \\
\text { CENTRAL }\end{array}$} \\
\hline Iowa & $2,470,939$ & -44.2 & -30.2 & -49.3 & 72.30 & 64.7 \\
\hline Kansas & $1,880,999$ & -108.2 & -87.3 & -118.1 & 100.80 & 81.8 \\
\hline Minnesota & $2,563,953$ & 9.3 & 13.3 & -14.0 & 129.50 & 27.8 \\
\hline Missouri & $3,629,367$ & -4.1 & -6 & -47.1 & 103.70 & 20.8 \\
\hline Nebraska & $1,377,963$ & -125.7 & -101.6 & -154.8 & 102.40 & 74.2 \\
\hline North Dakota & 680,845 & -188 & -155.9 & -195.3 & 134.50 & 127.7 \\
\hline South Dakota & 692,849 & -178.3 & -146.7 & -176.7 & 159.30 & 100.3 \\
\hline
\end{tabular}




\section{SOUTH}

\begin{tabular}{|c|c|c|c|c|c|c|}
\hline Virginia & $2,421,851$ & 10.2 & 1.2 & 36.3 & 81.40 & 6.3 \\
\hline Alabama & $2,646,248$ & -75.2 & -62.3 & -55.2 & 68.80 & 19.5 \\
\hline Arkansas & $1,854,482$ & -98.3 & -69.3 & -81.4 & 78.30 & 31.1 \\
\hline Florida & $1,468,211$ & 221.8 & 190.9 & 200.0 & 108.10 & 4.1 \\
\hline Georgia & $2,908,506$ & -63.5 & -46.5 & -22.9 & 64.80 & 18 \\
\hline Louisiana & $2,101,593$ & 1.9 & 2.9 & 8.2 & 84.80 & 21.9 \\
\hline Mississippi & $2,009,821$ & -65.6 & -45.1 & -28.3 & 62.00 & 28 \\
\hline North Carolina & $3,170,276$ & -35.5 & -26.9 & -9.4 & 53.80 & 17.5 \\
\hline South Carolina & $1,738,765$ & -75.5 & -59.1 & -18.4 & 90.80 & 21 \\
\hline Texas & $5,824,715$ & -23.7 & -12.5 & -6.9 & 78.80 & 37.4 \\
\hline Kentucky & $2,614,589$ & -38.3 & -35.9 & -41.9 & 74.10 & 17.6 \\
\hline Maryland & $1,631,526$ & 79.1 & 53.1 & 75.2 & 98.20 & 4.2 \\
\hline Oklahoma & $2,396,040$ & -159.8 & -112.4 & -153.5 & 101.30 & 38.5 \\
\hline Tennessee & $2,616,556$ & -10.6 & -5.8 & -29.6 & 63.00 & 14.4 \\
\hline West Virginia & $1,729,205$ & -48.7 & -42.5 & -31.5 & 108.70 & 1.6 \\
\hline \multicolumn{7}{|l|}{ MOUNTAIN } \\
\hline Arizona & 435,573 & 30.6 & -7.9 & 173.4 & 249.20 & 10.6 \\
\hline Colorado & $1,035,791$ & 6.6 & 0.6 & 17.6 & 172.70 & 28.7 \\
\hline Idaho & 445,032 & 48.2 & 45.7 & 73.6 & 145.00 & 46.8 \\
\hline Montana & 537,554 & -41 & -36.1 & -41.4 & 215.00 & 72.8 \\
\hline Nevada & 91,058 & 175.2 & 137.6 & 176.0 & 587.90 & 5.3 \\
\hline New Mexico & 423,317 & 77.2 & 43.9 & 65.1 & 176.60 & 23.9 \\
\hline Utah & 507,847 & -69.8 & -60.3 & -48.8 & 163.30 & 13.6 \\
\hline Wyoming & 225,565 & -2.1 & -0.5 & 24.3 & 213.90 & 31.2 \\
\hline \multicolumn{7}{|l|}{ PACIFIC } \\
\hline California & $5,677,251$ & 193.5 & 171.4 & 234.2 & 140.80 & 4.8 \\
\hline Oregon & 953,786 & 109.6 & 98.3 & 162.4 & 122.30 & 16 \\
\hline Washington & $1,563,396$ & 73.2 & 69.4 & 102.8 & 157.10 & 16.5 \\
\hline
\end{tabular}

${ }^{\text {a }}$ This estimate is 2 times the difference between immigrants to the state in 1940 and emigrants from the state in 1935.

Notes: Per capita New Deal spending in each state is computed as total spending in the state from 1933 to 1939 divided by the population in 1930. The figures in the table represent nominal spending. AAA includes payments to farmers under the Agricultural Adjustment Act, including rental and benefit payments in 1934 and 1935 and Conservation payments in 1936 and 1937. Relief and public works includes spending under the Federal Emergency Relief Administration, the Civil Works Administration, the Works Projects Administration, the Social Security programs for old-age assistance, aid to the blind, and aid to dependent children, the Public Works Administration, the Public Buildings Administration, and the Public Roads Administration.

Sources: See Appendix I. 
Table 2

OLS Estimates of Net Migration

\begin{tabular}{|c|c|c|c|c|c|c|}
\hline \multirow[t]{2}{*}{ Correlates include: } & \multicolumn{2}{|c|}{$\begin{array}{l}\text { Average annual } \\
\text { public works } \\
\text { and relief } \\
\text { spending per } \\
\text { capita }\end{array}$} & \multicolumn{2}{|c|}{$\begin{array}{c}\text { Average } \\
\text { annual AAA } \\
\text { spending per } \\
\text { capita }\end{array}$} & \multicolumn{2}{|c|}{$\begin{array}{l}\text { Retail sales per } \\
\text { capita, } 1929\end{array}$} \\
\hline & Coeff. & t-stat. & Coeff. & t-stat. & Coeff. & t-stat. \\
\hline Only New Deal variables & 0.220 & 4.10 & -0.377 & -7.91 & & \\
\hline $\begin{array}{l}\text { Only New Deal and retail } \\
\text { sales variables }\end{array}$ & 0.183 & 4.05 & -0.421 & -8.68 & 0.015 & 9.19 \\
\hline $\begin{array}{l}\text { New Deal variables, retail } \\
\text { sales, and state fixed effects }\end{array}$ & 0.186 & 4.00 & -0.267 & -4.61 & 0.011 & 4.64 \\
\hline $\begin{array}{l}\text { New Deal variables, retail } \\
\text { sales, and all other correlates }\end{array}$ & 0.146 & 4.62 & -0.155 & -2.81 & 0.007 & 1.68 \\
\hline $\begin{array}{l}\text { New Deal variables, retail } \\
\text { sales, all other correlates, and } \\
\text { state fixed effects }\end{array}$ & 0.178 & 5.11 & -0.108 & -1.76 & 0.008 & 2.03 \\
\hline
\end{tabular}

Notes: For a complete listing of the correlates used in the analysis, see Table 3.

Sources: See Appendix I. 
Table 3

OLS and 2SLS Net Migration Results

\begin{tabular}{|c|c|c|c|c|c|c|c|c|}
\hline \multirow{3}{*}{ Variables } & \multicolumn{4}{|c|}{$\begin{array}{l}\text { 2SLS second- } \\
\text { stage }\end{array}$} & \multicolumn{4}{|c|}{ 2SLS first-stage } \\
\hline & \multicolumn{2}{|c|}{ Net Migration } & \multicolumn{2}{|c|}{ Net Migration } & \multicolumn{2}{|c|}{$\begin{array}{l}\text { Public Works } \\
\text { per capita }\end{array}$} & \multicolumn{2}{|c|}{ AAA per capita } \\
\hline & Coeff. & t stat. & Coeff. & t stat. & Coeff. & t stat. & Coeff. & t stat. \\
\hline Intercept & 100.68 & 2.57 & 97.060 & 2.29 & -42.113 & -0.17 & -17.439 & -4.10 \\
\hline Endogenous Variables: & & & & & & & & \\
\hline $\begin{array}{l}\text { Average annual per capita New Deal } \\
\text { public works and relief spending }\end{array}$ & 0.178 & 5.11 & 0.517 & 2.31 & & & & \\
\hline $\begin{array}{l}\text { Average annual per capita AAA } \\
\text { spending }\end{array}$ & -0.108 & -1.76 & -0.182 & -1.73 & & & & \\
\hline Instrumental Variables: & & & & & & & & \\
\hline $\begin{array}{l}\text { Standard deviation of percent voting } \\
\text { for Democratic presidential }\end{array}$ & & & & & & & & \\
\hline candidate, $1896-1928$ & & & & & 0.137 & 1.96 & -0.044 & -0.62 \\
\hline Number of rivers in county spanning & & & & & & & & \\
\hline 11 to 20 total counties & & & & & 1.046 & 1.54 & -0.217 & -0.34 \\
\hline Number of rivers in county spanning & & & & & & & & \\
\hline 21 to 50 total counties & & & & & 0.838 & 2.46 & 0.459 & 0.47 \\
\hline Number of rivers in county spanning & & & & & & & & \\
\hline 51 or more total counties & & & & & 0.766 & 2.84 & 0.386 & 2.93 \\
\hline Average farm size, 1929 & & & & & -0.007 & -1.77 & 0.010 & 10.60 \\
\hline $\begin{array}{l}\text { Available water capacity (AWC) of } \\
\text { soil }\end{array}$ & & & & & -14.586 & -2.70 & 10.534 & 6.94 \\
\hline Independent Variables: & & & & & & & & \\
\hline Per capita retail sales, 1929 & 0.008 & 2.03 & 0.011 & 2.66 & -0.003 & -1.86 & 0.002 & 1.60 \\
\hline $\begin{array}{l}\text { Pct. of population over } 10 \text { years old } \\
\text { unemployed, } 1930\end{array}$ & -0.254 & -0.33 & -0.807 & -0.93 & 0.601 & 2.16 & -0.225 & -3.37 \\
\hline Pct. of population over 10 years old & & & & & & & & \\
\hline laid off, 1930 & -0.149 & -0.29 & -0.434 & -0.81 & 0.611 & 1.22 & -0.186 & -0.46 \\
\hline Pct. population owning homes, 1930 & 0.321 & 3.84 & 0.312 & 3.67 & 0.056 & 0.44 & 0.024 & 0.87 \\
\hline Pct. cultivated acreage that failed, & & & & & & & & \\
\hline 1929 & -0.134 & -1.17 & -0.163 & -1.43 & 0.119 & 0.75 & -0.054 & -1.93 \\
\hline Pct. farms owner-operated, 1929 & -0.199 & -3.87 & -0.206 & -4.00 & 0.031 & 0.41 & -0.014 & -0.84 \\
\hline "Dustbowl county" dummy variable & -15.551 & -4.03 & -14.41 & -2.94 & 2.176 & 3.18 & 3.936 & 5.51 \\
\hline Pct. population black, 1930 & 0.389 & 2.24 & 0.333 & 1.68 & 0.141 & 0.76 & -0.083 & -1.92 \\
\hline $\begin{array}{l}\text { Pct. population black, } 1930 \text { x South } \\
\text { dummy }\end{array}$ & -0.387 & -2.24 & -0.308 & -1.53 & -0.151 & -1.15 & 0.086 & 2.34 \\
\hline $\begin{array}{l}\text { Pct. population living in urban area, } \\
1930\end{array}$ & -0.030 & -0.72 & -0.031 & -0.63 & -0.026 & -1.44 & -0.012 & -7.15 \\
\hline Pct. of county's land in farm use, & & & & & & & & \\
\hline 1929 & -14.027 & -1.48 & -3.663 & -0.31 & -10.869 & -2.11 & 8.686 & 0.17 \\
\hline Pct. population foreign born, 1930 & 0.276 & 2.31 & 0.338 & 2.41 & -0.167 & -1.19 & 0.058 & 1.35 \\
\hline Pct. population illiterate, 1930 & 0.133 & 1.02 & 0.161 & 1.02 & -0.194 & -0.48 & -0.033 & -2.41 \\
\hline $\begin{array}{l}\text { Pct. population members of religious } \\
\text { denominations, } 1926\end{array}$ & -0.053 & -2.90 & -0.039 & -1.82 & -0.026 & -1.77 & 0.006 & 0.69 \\
\hline
\end{tabular}


Mean percent voting for Democratic presidential candidate, 1896-1928

Pct. population ages 10-19, 1930

Pct. population ages 20-29, 1930

Pct. population ages 30-34, 1930

Pct. population ages $35-44,1930$

Pct. population ages 45-54, 1930

Pct. population ages 55-64, 1930

Pct. population ages 65 up, 1930

Change in $\log$ (population), 1920 -

1930

Population, 1930

county land area

Average monthly temperature, 1930-

1940

Average monthly precipitation,

1930-1940

$\begin{array}{rrrrrrrr}0.069 & 1.50 & 0.072 & 1.50 & -0.035 & -0.26 & 0.012 & 0.34 \\ -1.884 & -3.51 & -1.817 & -3.04 & -0.680 & -0.08 & 0.214 & 0.46 \\ 0.457 & 0.66 & -0.121 & -0.15 & 0.997 & 1.62 & -0.196 & -1.24 \\ -0.597 & -0.46 & 0.254 & 0.18 & -1.459 & -1.65 & -0.588 & -0.16 \\ -0.483 & -0.68 & -0.979 & -1.17 & 0.947 & 1.69 & -0.350 & -0.93 \\ 0.479 & 0.75 & 0.413 & 0.60 & 0.581 & 0.54 & 0.323 & 1.85 \\ 2.098 & 2.15 & 1.457 & 1.37 & 0.808 & 2.19 & -0.390 & -1.00 \\ -0.764 & -0.81 & -0.499 & -0.49 & -0.915 & -1.23 & -0.271 & -1.87 \\ & & & & & & & \\ 7.827 & 2.68 & 9.420 & 3.33 & -1.682 & -3.24 & 1.320 & 2.05 \\ -0.003 & -1.99 & -0.003 & -1.70 & -0.001 & -0.98 & 0.001 & 4.17 \\ -0.001 & -1.38 & -0.001 & -1.70 & 0.001 & 0.81 & 0.000 & -2.30\end{array}$

Months of excess or severe drought,

1930-1940

Months of excess or severe wetness,

1930-1940

Pct. land in farm use $\mathrm{x}$ average

temperature

Pct. land in farm use $\mathrm{x}$ average

precipitation

Pct. land in farm use $\mathrm{x}$ months of

excess or severe drought

Pct. land in farm use $\mathrm{x}$ months of

excess or severe wetness

Latitude

Longitude

Elevation range

Maximum elevation

Number of bays

Number of lakes

Number of beaches

Number of swamps

Atlantic Coast county dummy

variable

Pacific Coast county dummy

variable

Gulf Coast county dummy variable

Great Lake county dummy variable

State dummy variables

$\mathrm{R}^{2}$

$\begin{array}{llllllll}-0.119 & -0.51 & 0.037 & 0.13 & -0.428 & -1.02 & 0.114 & 3.53\end{array}$

$\begin{array}{llllllll}-1.778 & -0.97 & -2.021 & -0.98 & 2.985 & 0.16 & -0.576 & -2.54\end{array}$

$\begin{array}{llllllll}-0.066 & -0.83 & -0.060 & -0.54 & -0.172 & -0.56 & -0.052 & -0.54\end{array}$

$\begin{array}{llllllll}-0.602 & -2.82 & -1.021 & -1.87 & 1.283 & 0.98 & 0.062 & 0.27\end{array}$

$\begin{array}{llllllll}-0.317 & -1.34 & -0.434 & -1.69 & 0.318 & 0.94 & -0.152 & -0.90\end{array}$

$\begin{array}{llllllll}5.780 & 2.32 & 5.974 & 2.09 & -3.899 & -0.44 & 0.966 & 1.53\end{array}$

$\begin{array}{llllllll}0.050 & 0.50 & 0.022 & 0.16 & 0.196 & 1.01 & 0.074 & 0.81\end{array}$

$\begin{array}{llllllll}0.318 & 1.28 & 0.672 & 1.05 & -1.495 & -0.77 & 0.096 & 0.85\end{array}$

$\begin{array}{llllllll}-1.497 & -3.33 & -1.497 & -3.17 & 0.424 & 0.61 & 0.201 & 1.49\end{array}$

$\begin{array}{llllllll}-0.027 & -0.12 & -0.028 & -0.10 & 0.274 & 0.54 & 0.087 & 6.89\end{array}$

$\begin{array}{llllllll}-0.002 & -2.56 & -0.002 & -2.73 & 0.001 & 0.76 & 0.000 & -1.62\end{array}$

$\begin{array}{llllllll}0.002 & 2.79 & 0.002 & 2.76 & -0.001 & -0.67 & 0.000 & 3.10\end{array}$

$\begin{array}{rrrrrrrr}-0.059 & -2.60 & -0.207 & -1.98 & 0.237 & 1.85 & 0.010 & 1.43\end{array}$

$\begin{array}{llllllll}0.008 & 1.44 & 0.016 & 2.20 & -0.011 & -2.01 & -0.003 & -0.14\end{array}$

$\begin{array}{llllllll}-0.045 & -0.45 & 0.074 & 0.38 & -0.387 & -0.98 & -0.033 & -0.60\end{array}$

$\begin{array}{llllllll}0.007 & 0.18 & 0.051 & 1.06 & -0.064 & -2.05 & -0.011 & -1.14\end{array}$

$\begin{array}{llllllll}2.864 & 1.28 & 4.766 & 1.74 & -4.526 & -1.07 & 0.549 & 1.16\end{array}$

$\begin{array}{llllllll}-8.877 & -2.37 & -8.842 & -2.13 & -4.982 & -0.18 & 1.247 & 2.16\end{array}$

$\begin{array}{llllllll}4.950 & 1.44 & 7.783 & 2.00 & -3.321 & -1.98 & -0.844 & -0.24\end{array}$

$\begin{array}{llllllll}-0.937 & -0.67 & -0.540 & -0.35 & -1.958 & -0.43 & 0.502 & 0.23\end{array}$

included included included included

0.318

3,048

3,048

3,048

3,048

Sources: See Appendix I. 


\section{Table 4 \\ Sensitivity of the 2SLS New Deal Results to Different Sets of Instruments}

$\begin{array}{lll}\text { Specification } \quad \text { Coeff. t-stat. } & \begin{array}{l}\text { t-statistics of individual } \\ \text { instruments in first-stage } \\ \text { equations }\end{array}\end{array}$

All six instruments included: Public works and relief spending

AAA

0.517

2.3

Standard deviation of AWC - 2.70

$-0.182 \quad-1.73 \quad$ Standard deviation of
Democratic vote 1.96; No. of rivers through 11-20 counties 1.54; No. of rivers through 21-50 counties 2.46; No. of rivers through $50+$ counties 2.84 ; average farm size, 1929 -1.77; Democratic vote -0.62 ; No. of rivers through 11-20 counties -0.34 ; No. of rivers through 21 50 counties 0.47 ; No. of rivers through 50+ counties 2.93; average farm size, 1929 10.60; AWC 6.94

Standard deviation of Democratic vote excluded from set of instruments:

Public works and $\quad 0.425$ relief spending

1.90

No. of rivers through 11-20 counties 1.52; No. of rivers through 21-50 counties 2.38; No. of rivers through $50+$ counties 2.69; average farm size, 1929 -1.72; AWC -2.82

AAA $-0.195$

No. of rivers through 11-20 counties -0.32 ; No. of rivers through 21-50 counties 0.48; No. of rivers through $50+$ counties 2.96; average farm size, 1929 10.61; AWC 6.91

\section{F-statistic that identifying instruments are simultaneously equal to 0 in first- stage equations}

\author{
Hausman test \\ rejects no \\ correlation of \\ instruments \\ with estimate \\ of second- \\ stage error ${ }^{1}$
}

Three river dummy variables excluded:
Public works and $\quad 0.735 \quad 1.74 \quad$ Standard deviation of relief spending
AAA

$-0.147$

Average farm size excluded

Public works and $\quad 0.49$ relief spending
0.490 2.18 Standard deviation of Democratic vote 1.93; No. of

\subsection{3 no}

4.16 no 
rivers through 11-20 counties

1.55; No. of rivers through 21-50

counties 2.41 ; No. of rivers

through 50+ counties 2.86;

AWC - 2.74

AAA

$-0.251 \quad-1.40 \quad$ Standard deviation of

15.01

Democratic vote 0.35 ; No. of

rivers through 11-20 counties

-0.84 ; No. of rivers through 21 -

50 counties 1.12 ; No. of rivers

through 50+ counties 2.22;

AWC 7.72

Available water capacity excluded:

Public works and

relief spending

AAA
0.486

2.04

Standard deviation of

Democratic vote 2.09; No. of rivers through 11-20 counties

1.55; No. of rivers through 21-50

counties 2.54 ; No. of rivers

through 50+ counties 2.52;

average farm size, $1929-1.88$

$-0.180 \quad-1.71 \quad$ Standard deviation of

Democratic vote -1.58 ; No. of

rivers through 11-20 counties

-0.44 ; No. of rivers through 21 -

50 counties 0.14 ; No. of rivers

through 50+ counties 3.96;

average farm size, 192910.54
3.81 no

25.63

${ }^{1}$ In the Hausman overidentification test the chi-square value was below 1.5 in these comparisons, well below the critical value for rejection of the hypothesis that the identifying instruments were inappropriately omitted from the migration equation at the 90 percent level.

Notes. We have also removed each of the river variables one by one and found results within the same range that we report here. 
Table 5

\section{G2SLS Net Migration Results}

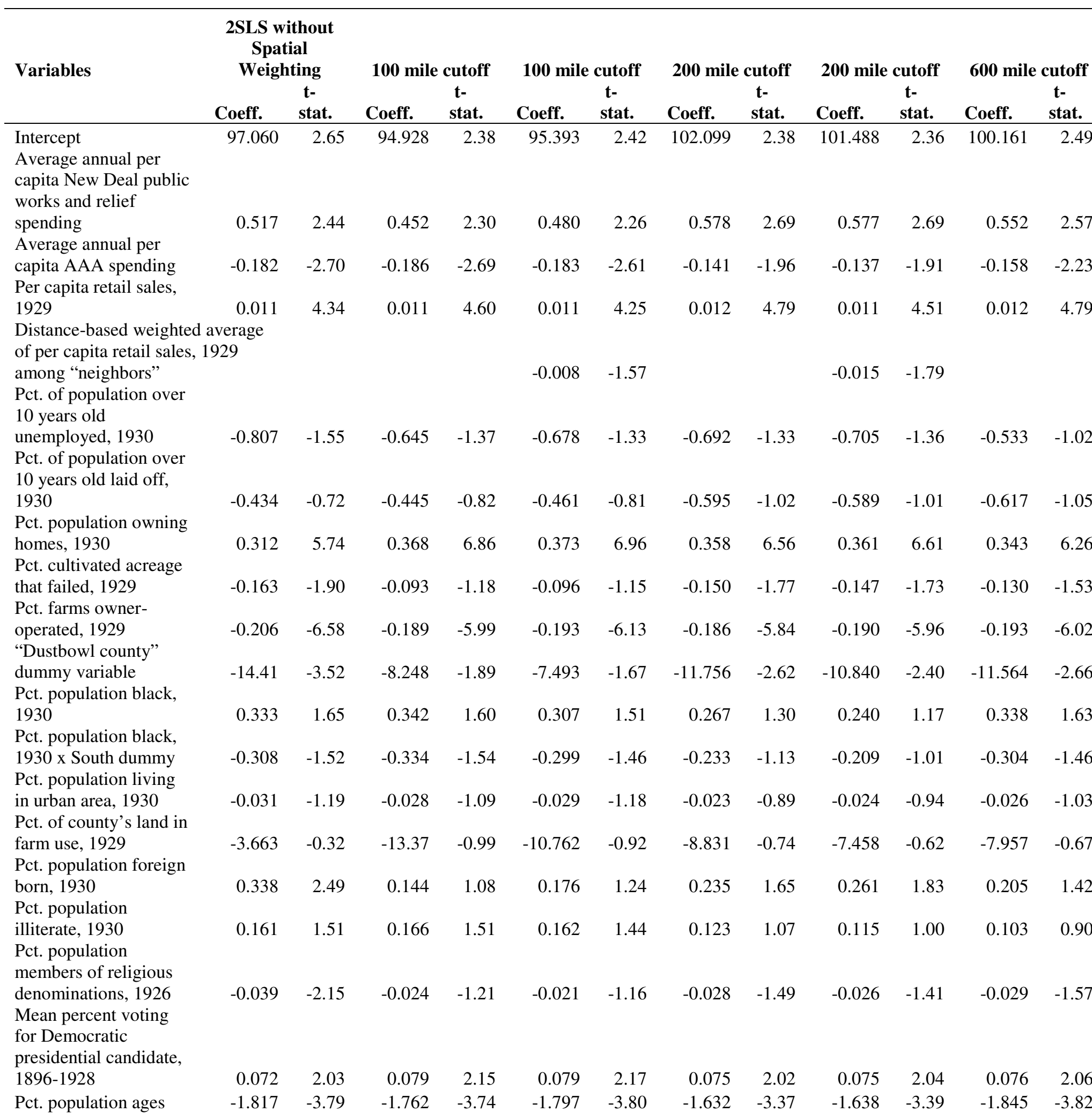


10-19, 1930

Pct. population ages

20-29, 1930

Pct. population ages

30-34, 1930

Pct. population ages

35-44, 1930

Pct. population ages

45-54, 1930

Pct. population ages

55-64, 1930

Pct. population ages 65

up, 1930

Change in

$\log$ (population), 1920 -

1930

Population, 1930

county land area

Average monthly

temperature, 1930-1940

Average monthly

precipitation, 1930-

1940

Months of excess or

severe drought, 1930-

1940

Months of excess or

severe wetness, 1930-

1940

Pct. land in farm use $\mathrm{x}$

average temperature

Pct. land in farm use $\mathrm{x}$ average precipitation

Pct. land in farm use $x$

months of excess or

severe drought

\begin{tabular}{|c|c|c|c|c|c|c|c|c|c|c|}
\hline-0.121 & -0.24 & 0.173 & 0.22 & 0.149 & 0.30 & -0.138 & -0.28 & -0.118 & -0.24 & -0.207 \\
\hline 0.254 & 0.23 & 0.395 & 0.46 & 0.523 & 0.50 & 0.839 & 0.78 & 0.926 & 0.86 & 0.636 \\
\hline-0.979 & -1.55 & -0.563 & -1.05 & -0.582 & -0.95 & -0.858 & -1.37 & -0.796 & -1.27 & -0.970 \\
\hline 0.413 & 0.74 & 0.666 & 1.18 & 0.698 & 1.27 & 0.693 & 1.24 & 0.731 & 1.31 & 0.603 \\
\hline 1.457 & 1.76 & 1.065 & 1.24 & 1.046 & 1.31 & 0.823 & 1.01 & 0.869 & 1.06 & 1.063 \\
\hline-0.499 & -0.78 & -0.250 & -0.34 & -0.189 & -0.30 & -0.098 & -0.15 & -0.058 & -0.09 & -0.350 \\
\hline 9.420 & 5.24 & 2.974 & 1.68 & 3.355 & 1.81 & 5.617 & 2.96 & 5.905 & 3.10 & 5.564 \\
\hline-0.003 & -1.36 & -0.002 & -1.10 & -0.002 & -1.12 & -0.002 & -1.15 & -0.002 & -1.16 & -0.002 \\
\hline-0.001 & -2.42 & -0.001 & -2.15 & -0.001 & -2.18 & -0.001 & -2.28 & -0.001 & -2.25 & -0.001 \\
\hline 0.037 & 0.15 & -0.014 & 0.06 & 0.019 & 0.07 & 0.040 & 0.15 & 0.040 & 0.15 & 0.083 \\
\hline-2.021 & -1.70 & -3.214 & -2.48 & -3.353 & -2.57 & -3.188 & -2.37 & -3.324 & -2.46 & -2.498 \\
\hline-0.060 & -0.80 & -0.123 & -1.42 & -0.113 & -1.39 & -0.079 & -0.98 & -0.073 & -0.90 & -0.101 \\
\hline
\end{tabular}

Pct. land in farm use $x$

months of excess or

severe wetness

Latitude

Longitude

Elevation range

Maximum elevation

Number of bays

Number of lakes

Number of beaches

Number of swamps

Atlantic Coast county

dummy variable

Pacific Coast county

dummy variable

Gulf Coast county

dummy variable

Great Lake county

dummy variable

\begin{tabular}{|c|c|c|c|c|c|c|c|c|c|c|}
\hline & & & & & & & & & & \\
\hline-1.021 & -3.30 & -1.118 & -3.72 & -1.132 & -3.63 & -1.177 & -3.70 & -1.163 & -3.66 & -1.060 \\
\hline-0.434 & -2.12 & -0.309 & -1.56 & -0.313 & -1.52 & -0.302 & -1.44 & -0.294 & -1.41 & -0.369 \\
\hline 5.974 & 3.30 & 5.850 & 3.05 & 5.443 & 2.87 & 5.480 & 2.85 & 5.074 & 2.62 & 6.161 \\
\hline 0.022 & 0.21 & 0.079 & 0.54 & 0.055 & 0.50 & 0.006 & 0.06 & -0.004 & -0.03 & 0.049 \\
\hline 0.672 & 2.13 & 0.827 & 2.69 & 0.844 & 2.62 & 0.825 & 2.52 & 0.815 & 2.49 & 0.703 \\
\hline-1.497 & -3.82 & -1.487 & -3.33 & -1.442 & -3.24 & -1.473 & -2.96 & -1.362 & -2.71 & -1.453 \\
\hline-0.028 & -0.13 & -0.088 & -0.33 & -0.057 & -0.23 & -0.224 & -0.84 & -0.161 & -0.60 & -0.151 \\
\hline-0.002 & -4.20 & -0.002 & -3.26 & -0.002 & -3.27 & -0.002 & -3.70 & -0.002 & -3.69 & -0.002 \\
\hline 0.002 & 4.11 & 0.002 & 2.91 & 0.002 & 2.92 & 0.002 & 3.29 & 0.002 & 3.28 & 0.002 \\
\hline-0.207 & -2.13 & -0.213 & -2.37 & -0.226 & -2.32 & -0.239 & -2.43 & -0.239 & -2.42 & -0.214 \\
\hline 0.016 & 1.81 & 0.014 & 1.65 & 0.014 & 1.66 & 0.017 & 1.94 & 0.017 & 1.95 & 0.014 \\
\hline 0.074 & 0.48 & 0.120 & 0.93 & 0.135 & 0.90 & 0.130 & 0.85 & 0.133 & 0.87 & 0.113 \\
\hline 0.051 & 0.95 & 0.064 & 1.29 & 0.068 & 1.26 & 0.070 & 1.27 & 0.071 & 1.29 & 0.065 \\
\hline 4.766 & 2.03 & 4.001 & 1.70 & 4.294 & 1.76 & 4.943 & 2.00 & 5.166 & 2.08 & 4.461 \\
\hline-8.842 & -2.46 & -0.711 & -0.10 & -0.224 & -0.05 & -2.714 & -0.66 & -2.484 & -0.60 & 4.471 \\
\hline 7.783 & 2.53 & 8.274 & 2.65 & 8.331 & 2.63 & 8.796 & 2.73 & 8.764 & 2.72 & 7.077 \\
\hline-0.540 & -0.23 & -0.274 & -0.13 & -0.222 & -0.09 & -0.544 & -0.23 & -0.526 & -0.22 & -0.530 \\
\hline
\end{tabular}




\begin{tabular}{|c|c|c|c|c|c|c|}
\hline State dummy variables & included & included & included & included & included & included \\
\hline $\mathrm{P}$ & & 0.537 & 0.539 & 0.807 & 0.810 & 2.77 \\
\hline$\sigma^{2}$ & 256.7 & 226.2 & 224.8 & 238.6 & 238.4 & 240.7 \\
\hline $\mathrm{N}$ & 3,048 & 3,048 & 3,048 & 3,048 & 3,048 & 3,048 \\
\hline
\end{tabular}

\section{Sources: See Appendixes I and II}


Table 6

\section{Decompositions of Difference in Net Migration Between Counties with Positive and Negative Net Migration}

\begin{tabular}{|c|c|c|c|c|c|c|c|}
\hline Variables & $\begin{array}{l}\text { Difference } \\
\text { in means } \\
\text { between } \\
\text { two } \\
\text { groups of } \\
\text { counties }\end{array}$ & \multicolumn{3}{|c|}{$\begin{array}{l}\text { Percentage of difference } \\
\text { in net migration between } \\
\text { two groups of counties } \\
\text { explained by the } \\
\text { difference in means of } \\
\text { variable }\end{array}$} & \multicolumn{3}{|c|}{$\begin{array}{l}\text { The effect of a one- } \\
\text { standard-deviation } \\
\text { increase in variable (as a } \\
\text { share of the standard } \\
\text { deviation of the net } \\
\text { migration rate) }\end{array}$} \\
\hline Net migration rate per 1,000 population & & & & & & & \\
\hline 1930 & 25.773 & & & & & & \\
\hline $\begin{array}{l}\text { Average annual per capita New Deal public } \\
\text { works and relief spending }\end{array}$ & 7.991 & 5.508 & 16.026 & 14.891 & 0.167 & 0.536 & 0.498 \\
\hline Average annual per capita AAA spending & -6.861 & 2.881 & 4.844 & 4.884 & -0.049 & -0.133 & -0.134 \\
\hline Per capita retail sales, 1929 & 159.215 & 5.220 & 6.944 & 6.541 & 0.240 & 0.159 & 0.149 \\
\hline $\begin{array}{l}\text { Distance-based weighted average of per } \\
\text { capita retail sales, } 1929 \text { among "neighbors" }\end{array}$ & 159.215 & & & -4.940 & 0.000 & 0.000 & -0.117 \\
\hline $\begin{array}{l}\text { Pct. of population over } 10 \text { years old } \\
\text { unemployed, } 1930\end{array}$ & 0.723 & -0.712 & -2.266 & -1.902 & -0.017 & -0.046 & -0.038 \\
\hline $\begin{array}{l}\text { Pct. of population over } 10 \text { years old laid off, } \\
1930\end{array}$ & 0.149 & -0.086 & -0.251 & -0.267 & -0.004 & -0.014 & -0.015 \\
\hline Pct. population owning homes, 1930 & 3.580 & 4.456 & 4.334 & 5.176 & 0.880 & 0.220 & 0.263 \\
\hline Pct. cultivated acreage that failed, 1929 & 0.539 & -0.280 & -0.340 & -0.201 & -0.022 & -0.035 & -0.021 \\
\hline Pct. farms owner-operated, 1929 & 4.559 & -3.518 & -3.652 & -3.413 & -0.660 & -0.183 & -0.171 \\
\hline "Dustbowl county" dummy variable & -0.019 & 1.117 & 1.035 & 0.538 & -0.013 & -0.095 & -0.049 \\
\hline Pct. population black, 1930 & -4.090 & -6.176 & -5.285 & -4.870 & 0.225 & 0.319 & 0.294 \\
\hline Pct. population black, $1930 \mathrm{x}$ South dummy & -4.739 & 7.112 & 5.663 & 5.501 & -0.213 & -0.299 & -0.290 \\
\hline Pct. population living in urban area, 1930 & 14.185 & -1.661 & -1.693 & -1.612 & -0.033 & -0.040 & -0.038 \\
\hline Pct. of county's land in farm use, 1929 & -0.170 & 9.240 & 2.413 & 7.090 & -0.473 & -0.052 & -0.153 \\
\hline Pct. population foreign born, 1930 & 2.579 & 2.764 & 3.379 & 1.765 & 0.068 & 0.104 & 0.054 \\
\hline Pct. population illiterate, 1930 & -1.095 & -0.565 & -0.682 & -0.690 & 0.038 & 0.049 & 0.050 \\
\hline $\begin{array}{l}\text { Pct. population members of religious } \\
\text { denominations, } 1926\end{array}$ & -3.634 & 0.745 & 0.552 & 0.302 & -0.133 & -0.049 & -0.027 \\
\hline $\begin{array}{l}\text { Mean percent voting for Democratic } \\
\text { presidential candidate, 1896-1928 }\end{array}$ & -5.159 & -1.389 & -1.435 & -1.586 & 0.179 & 0.069 & 0.077 \\
\hline Pct. population ages 10-19, 1930 & -2.370 & 17.320 & 16.707 & 16.520 & -2.073 & -0.260 & -0.257 \\
\hline Pct. population ages 20-29, 1930 & 0.087 & 0.154 & -0.041 & 0.050 & 0.376 & -0.013 & 0.016 \\
\hline Pct. population ages 30-34, 1930 & 0.468 & -1.084 & 0.462 & 0.950 & -0.201 & 0.012 & 0.025 \\
\hline Pct. population ages 35-44, 1930 & 1.293 & -2.423 & -4.912 & -2.922 & -0.312 & -0.088 & -0.053 \\
\hline Pct. population ages $45-54,1930$ & 1.204 & 2.238 & 1.928 & 3.262 & 0.251 & 0.035 & 0.058 \\
\hline Pct. population ages 55-64, 1930 & 1.111 & 9.046 & 6.281 & 4.508 & 0.747 & 0.138 & 0.099 \\
\hline Pct. population ages 65 up, 1930 & 0.980 & -2.904 & -1.897 & -0.718 & -0.231 & -0.058 & -0.022 \\
\hline Change in $\log$ (population), $1920-1930$ & 0.093 & 2.822 & 3.396 & 1.209 & 0.031 & 0.138 & 0.049 \\
\hline Population, 1930 & 28.217 & -0.336 & -0.289 & -0.226 & -0.006 & -0.024 & -0.019 \\
\hline county land area & 400.776 & -1.113 & -1.525 & -1.313 & -0.036 & -0.068 & -0.058 \\
\hline Average monthly temperature, $1930-1940$ & -2.114 & 0.978 & -0.300 & -0.154 & -0.344 & 0.016 & 0.008 \\
\hline Average monthly precipitation, $1930-1940$ & -0.041 & 0.286 & 0.325 & 0.539 & -0.272 & -0.119 & -0.197 \\
\hline
\end{tabular}


Months of excess or severe drought, 19301940

Months of excess or severe wetness, 19301940

Pct. land in farm use $\mathrm{x}$ average temperature

Pct. land in farm use $x$ average precipitation Pct. land in farm use $\mathrm{x}$ months of excess or severe drought

Pct. land in farm use $\mathrm{x}$ months of excess or severe wetness

Latitude

Longitude

Elevation range

Maximum elevation

Number of bays

Number of lakes

Number of beaches

Number of swamps

Atlantic Coast county dummy variable

Pacific Coast county dummy variable

Gulf Coast county dummy variable

Great Lake county dummy variable

$\begin{array}{rrrrrrr}-2.270 & 0.578 & 0.528 & 0.996 & -0.078 & -0.053 & -0.100 \\ 0.416 & -0.972 & -1.648 & -1.827 & -0.109 & -0.282 & -0.312 \\ -10.240 & 12.608 & 17.256 & 12.441 & -0.589 & -0.348 & -0.251 \\ -0.437 & -9.803 & -10.13 & -9.230 & 0.557 & 0.290 & 0.264 \\ & & & & & & \\ -5.984 & -1.155 & -0.507 & -1.271 & 0.041 & 0.017 & 0.043 \\ & & & & & & \\ -0.442 & -0.546 & -1.152 & -1.448 & 0.037 & 0.142 & 0.179 \\ 1.007 & -5.848 & -5.850 & -5.634 & -2.985 & -0.381 & -0.367 \\ 1.936 & -0.202 & -0.207 & -0.431 & -0.129 & -0.017 & -0.034 \\ 1179.637 & -9.108 & -11.35 & -8.725 & -0.159 & -0.306 & -0.235 \\ 1197.769 & 9.062 & 11.132 & 8.120 & 0.245 & 0.371 & 0.271 \\ 4.028 & -0.921 & -3.231 & -3.529 & -0.009 & -0.151 & -0.165 \\ 24.142 & 0.756 & 1.476 & 1.345 & 0.009 & 0.046 & 0.042 \\ 1.054 & -0.183 & 0.302 & 0.551 & -0.001 & 0.012 & 0.022 \\ 1.821 & 0.050 & 0.362 & 0.481 & 0.001 & 0.022 & 0.029 \\ 0.051 & 0.572 & 0.952 & 0.858 & 0.006 & 0.050 & 0.045 \\ 0.036 & -1.251 & -1.246 & -0.032 & -0.006 & -0.053 & -0.001 \\ 0.022 & 0.419 & 0.659 & 0.706 & 0.004 & 0.053 & 0.057 \\ 0.021 & -0.077 & -0.044 & -0.018 & -0.001 & -0.005 & -0.002\end{array}$

Share of Difference in Net Migration

Between Two Groups of Counties

Explained by All Endogenous and

Independent Variables

$\begin{array}{lll}43.62 & 47.02 \quad 42.26\end{array}$ 


\section{Appendix Table III-1}

Comparisons of Various State Estimates of Net Migration During the 1930s

\begin{tabular}{|c|c|c|c|c|c|c|}
\hline \multirow[t]{2}{*}{ State } & \multirow[b]{2}{*}{$\begin{array}{l}\text { Population in } \\
1930\end{array}$} & \multicolumn{3}{|c|}{ Fishback/Horrace/Kantor Method } & \multirow[b]{2}{*}{$\begin{array}{l}\text { Gardner and } \\
\text { Cohen }\end{array}$} & \multirow[b]{2}{*}{$\begin{array}{l}\text { Estimate } \\
\text { based on } \\
\text { Census } \\
\text { measures of } \\
1940 \\
\text { immigrants } \\
\text { minus } 1935 \\
\text { emigrants* }\end{array}$} \\
\hline & & $\begin{array}{l}\text { Unadjusted } \\
\text { for birth } \\
\text { undercount }\end{array}$ & $\begin{array}{l}\text { Adjusted for } \\
\text { Birth } \\
\text { Undercount }\end{array}$ & $\begin{array}{l}\text { Adjusted for } \\
\text { Black and } \\
\text { White Birth } \\
\text { Undercounts }\end{array}$ & & \\
\hline \multicolumn{7}{|c|}{ NEW ENGLAND } \\
\hline Connecticut & $1,606,903$ & 33.1 & 31.1 & 31.1 & 23.6 & 31.0 \\
\hline Maine & 797,423 & 16.9 & 8.9 & 9.3 & -2.1 & -21.6 \\
\hline Massachusetts & $4,249,614$ & -10.2 & -11.0 & -11.1 & -17.0 & -15.2 \\
\hline New & 465,293 & 34.1 & 29.1 & 29.1 & 18.7 & 26.3 \\
\hline \multicolumn{7}{|l|}{ Hampshire } \\
\hline Rhode Island & 687,497 & 7.1 & 3.9 & 3.9 & -4.0 & 1.2 \\
\hline Vermont & 359,611 & -38.9 & -49.4 & -49.8 & -52.5 & -31.9 \\
\hline \multicolumn{7}{|c|}{ MID-ATLANTIC } \\
\hline Delaware & 238,380 & 89.1 & 86.9 & 86.7 & 66.8 & 86.6 \\
\hline New Jersey & $4,041,334$ & 2.6 & 0.6 & 0.6 & -7.4 & 14.5 \\
\hline New York & $12,588,066$ & 45.0 & 43.9 & 44.0 & 31.1 & -9.1 \\
\hline Pennsylvania & $9,631,350$ & -20.1 & -24.3 & -23.9 & -31.5 & -21.5 \\
\hline \multicolumn{7}{|c|}{ EAST NORTH CENTRAL } \\
\hline Illinois & $7,630,654$ & 4.0 & -2.0 & -1.9 & -8.4 & -5.0 \\
\hline Indiana & $3,238,503$ & 18.6 & 10.9 & 10.9 & 3.1 & 16.2 \\
\hline Michigan & $4,842,325$ & 14.6 & 11.0 & 10.8 & 3.3 & 31.4 \\
\hline Ohio & $6,646,697$ & 4.2 & -3.8 & -4.1 & -8.7 & -2.9 \\
\hline Wisconsin & $2,939,006$ & 0.0 & -7.7 & -7.5 & -4.3 & -21.6 \\
\hline \multicolumn{7}{|c|}{ WEST NORTH CENTRAL } \\
\hline Iowa & $2,470,939$ & -28.8 & -44.2 & -44.4 & -30.2 & -49.3 \\
\hline Kansas & $1,880,999$ & -94.6 & -108.2 & -108.6 & -87.3 & -118.1 \\
\hline Minnesota & $2,563,953$ & 14.5 & 9.3 & 9.2 & 13.3 & -14.0 \\
\hline Missouri & $3,629,367$ & 12.0 & -4.1 & -4.0 & -6.0 & -47.1 \\
\hline Nebraska & $1,377,963$ & -117.7 & -125.7 & -125.6 & -101.6 & -154.8 \\
\hline North Dakota & 680,845 & -166.5 & -188.0 & -188.4 & -155.9 & -195.3 \\
\hline South Dakota & 692,849 & -159.2 & -178.3 & -176.4 & -146.7 & -176.7 \\
\hline \multicolumn{7}{|l|}{ SOUTH } \\
\hline Virginia & $2,421,851$ & 26.9 & 10.2 & 11.7 & 1.2 & 36.3 \\
\hline Alabama & $2,646,248$ & -38.7 & -75.2 & -73.3 & -62.3 & -55.2 \\
\hline Arkansas & $1,854,482$ & -44.8 & -98.3 & -97.7 & -69.3 & -81.4 \\
\hline Florida & $1,468,211$ & 245.5 & 221.8 & 224.5 & 190.9 & 200.0 \\
\hline Georgia & $2,908,506$ & -12.8 & -63.5 & -58.9 & -46.5 & -22.9 \\
\hline
\end{tabular}




\begin{tabular}{|c|c|c|c|c|c|c|}
\hline Louisiana & $2,101,593$ & 42.4 & 1.9 & 4.2 & 2.9 & 8.2 \\
\hline Mississippi & $2,009,821$ & -31.1 & -65.6 & -59.7 & -45.1 & -28.3 \\
\hline North Carolina & $3,170,276$ & 2.4 & -35.5 & -32.7 & -26.9 & -9.4 \\
\hline South Carolina & $1,738,765$ & -8.2 & -75.5 & -60.9 & -59.1 & -18.4 \\
\hline Texas & $5,824,715$ & 21.9 & -23.7 & -24.6 & -12.5 & -6.9 \\
\hline Kentucky & $2,614,589$ & -8.0 & -38.3 & -39.0 & -35.9 & -41.9 \\
\hline Maryland & $1,631,526$ & 85.5 & 79.1 & 80.2 & 53.1 & 75.2 \\
\hline Oklahoma & $2,396,040$ & -110.0 & -159.8 & -160.3 & -112.4 & -153.5 \\
\hline Tennessee & $2,616,556$ & 40.4 & -10.6 & -9.4 & -5.8 & -29.6 \\
\hline $\begin{array}{l}\text { West Virginia } \\
\text { MOUNTAIN }\end{array}$ & $1,729,205$ & -15.1 & -48.7 & -49.1 & -42.5 & -31.5 \\
\hline Arizona & 435,573 & 86.6 & 30.6 & 56.8 & -7.9 & 173.4 \\
\hline Colorado & $1,035,791$ & 38.4 & 6.6 & 6.3 & 0.6 & 17.6 \\
\hline Idaho & 445,032 & 68.5 & 48.2 & 48.5 & 45.7 & 73.6 \\
\hline Montana & 537,554 & -30.1 & -41.0 & -40.3 & -36.1 & -41.4 \\
\hline Nevada & 91,058 & 195.9 & 175.2 & 177.1 & 137.6 & 176.0 \\
\hline New Mexico & 423,317 & 127.5 & 77.2 & 95.6 & 43.9 & 65.1 \\
\hline Utah & 507,847 & -58.5 & -69.8 & -68.9 & -60.3 & -48.8 \\
\hline Wyoming & 225,565 & 15.6 & -2.1 & -1.8 & -0.5 & 24.3 \\
\hline \multicolumn{7}{|l|}{ PACIFIC } \\
\hline California & $5,677,251$ & 198.2 & 193.5 & 193.2 & 171.4 & 234.2 \\
\hline Oregon & 953,786 & 117.2 & 109.6 & 109.9 & 98.3 & 162.4 \\
\hline Washington & $1,563,396$ & 80.4 & 73.2 & 73.5 & 69.4 & 102.8 \\
\hline
\end{tabular}

* This estimate is 2 times the difference between immigrants to the state in 1940 and emigrants from the state in 1935.

Sources: See Appendices I and II. 


\section{Appendix Table IV-1}

Decision Tree for Populations in Counties 1 and 2 and How They Affect Births, Deaths, Out-Migration and In-Migration

\begin{tabular}{|c|c|c|c|c|c|c|c|c|c|c|c|c|c|c|c|c|c|}
\hline \multirow[t]{2}{*}{ Variable } & \multirow[t]{2}{*}{ Cty 1} & & & & \multicolumn{2}{|c|}{$\begin{array}{l}\text { In } \\
\text { population } \\
\text { in } 1930 \text { in }\end{array}$} & \multicolumn{2}{|c|}{ In population in 1940 in } & \multicolumn{2}{|c|}{ Births } & \multicolumn{2}{|c|}{ Deaths } & \multicolumn{2}{|c|}{ Inmigrant } & \multicolumn{2}{|c|}{ outmigrant } & \multirow[t]{2}{*}{ variable } \\
\hline & & & & $\begin{array}{l}\text { Where } \\
\text { in } \\
1940\end{array}$ & $\begin{array}{l}\text { cty } \\
1\end{array}$ & $\begin{array}{l}\text { cty } \\
2\end{array}$ & Cty 1 & Cty 2 & cty1 & cty2 & cty1 & cty2 & cty1 & cty2 & ct1 & cty 2 & \\
\hline ps11 & \multirow{5}{*}{$\begin{array}{l}\text { In cty } \\
1 \text { in } \\
1930\end{array}$} & $\begin{array}{l}\text { stays in } \\
\text { cty } 1 \\
\text { through } \\
1940\end{array}$ & & Cty 1 & yes & no & yes & no & zero & zero & zero & zero & zero & zero & zero & zero & ps11 \\
\hline $\mathrm{p} 1 \mathrm{~m} 2 \mathrm{~s} 2$ & & \multirow{3}{*}{$\begin{array}{l}\text { migrates } \\
\text { to cty } 2 \\
\text { pre } \\
1940\end{array}$} & $\begin{array}{l}\text { stays in } \\
\text { cty } 2 \\
\text { through } \\
1940\end{array}$ & Cty 2 & yes & no & no & $\begin{array}{l}\text { yes as } \\
\text { inmigrant }\end{array}$ & zero & zero & zero & zero & zero & add & add & zero & $\mathrm{p} 1 \mathrm{~m} 2 \mathrm{~s} 2$ \\
\hline $\mathrm{p} 1 \mathrm{~m} 2 \mathrm{~m} 1$ & & & $\begin{array}{l}\text { returns } \\
\text { to cty } 1 \\
\text { pre } \\
1940\end{array}$ & Cty 1 & yes & no & $\begin{array}{l}\text { Yes } \\
\text { (returned) }\end{array}$ & $\begin{array}{l}\text { no left } \\
\text { after came }\end{array}$ & zero & zero & zero & zero & add & add & add & add & $\mathrm{p} 1 \mathrm{~m} 2 \mathrm{~m} 1$ \\
\hline $\mathrm{p} 1 \mathrm{~m} 2 \mathrm{~d} 2$ & & & $\begin{array}{l}\text { dies in } \\
\text { cty } 2 \\
\text { pre } \\
1940\end{array}$ & $\begin{array}{l}\text { neither } \\
\text { cty }\end{array}$ & yes & no & no & $\begin{array}{l}\text { no died } \\
\text { before } \\
1940\end{array}$ & zero & zero & zero & add & zero & add & zero & zero & $\mathrm{p} 1 \mathrm{~m} 2 \mathrm{~d} 2$ \\
\hline p1d1 & & $\begin{array}{l}\text { dies in } \\
\text { cty } 1 \\
\text { before } \\
1940\end{array}$ & & $\begin{array}{l}\text { neither } \\
\text { cty }\end{array}$ & yes & no & no & zero & zero & zero & add & zero & zero & zero & zero & zero & $\mathrm{p} 1 \mathrm{~d} 1$ \\
\hline
\end{tabular}




\begin{tabular}{|c|c|c|c|c|c|c|c|c|c|c|c|c|c|c|c|c|c|}
\hline \multirow[t]{2}{*}{ Variable } & \multirow[t]{2}{*}{ Cty 1} & & & & \multicolumn{2}{|c|}{$\begin{array}{l}\text { In } \\
\text { population } \\
\text { in } 1930 \text { in }\end{array}$} & \multicolumn{2}{|c|}{ In population in 1940 in } & \multicolumn{2}{|c|}{ Births } & \multicolumn{2}{|c|}{ Deaths } & \multicolumn{2}{|c|}{ Inmigrant } & \multicolumn{2}{|c|}{ outmigrant } & variable \\
\hline & & & & $\begin{array}{l}\text { Where } \\
\text { in } \\
1940 \\
\end{array}$ & $\begin{array}{l}\text { cty } \\
1\end{array}$ & $\begin{array}{l}\text { cty } \\
2\end{array}$ & Cty 1 & Cty 2 & cty 1 & cty 2 & cty 1 & cty2 & cty 1 & cty 2 & ct1 & cty 2 & \\
\hline b1s1 & \multirow{5}{*}{$\begin{array}{l}\text { Born } \\
\text { in cty } \\
1 \text { after } \\
1930\end{array}$} & $\begin{array}{l}\text { stays in } \\
\text { cty } 1 \\
\text { through } \\
1940 \\
\end{array}$ & & Cty 1 & No & no & yes & zero & add & zero & zero & zero & zero & zero & zero & zero & b1s1 \\
\hline b1m2s2 & & \multirow{3}{*}{$\begin{array}{l}\text { migrates } \\
\text { to cty } 2 \\
\text { pre } \\
1940\end{array}$} & $\begin{array}{l}\text { stays in } \\
\text { cty } 2 \\
\text { through } \\
1940 \\
\end{array}$ & Cty 2 & No & no & no & $\begin{array}{l}\text { yes } \\
\text { inmigrant }\end{array}$ & add & zero & zero & zero & zero & add & add & zero & b1m2s2 \\
\hline $\mathrm{b} 1 \mathrm{~m} 2 \mathrm{~m} 1$ & & & $\begin{array}{l}\text { returns } \\
\text { to cty } 1 \\
\text { pre } \\
1940\end{array}$ & Cty 1 & No & no & $\begin{array}{l}\text { yes } \\
\text { (returned) }\end{array}$ & $\begin{array}{l}\text { no (left } \\
\text { after } \\
\text { migrated) }\end{array}$ & add & zero & zero & zero & add & add & add & add & $\mathrm{b} 1 \mathrm{~m} 2 \mathrm{~m} 1$ \\
\hline $\mathrm{b} 1 \mathrm{~m} 2 \mathrm{~d} 2$ & & & $\begin{array}{l}\text { dies in } \\
\text { cty } 2 \\
\text { pre } \\
1940 \\
\end{array}$ & neither & No & no & no died & no died & add & zero & zero & add & zero & add & add & zero & $\mathrm{b} 1 \mathrm{~m} 2 \mathrm{~d} 2$ \\
\hline b1d1 & & $\begin{array}{l}\text { dies in } \\
\text { cty } 1 \\
\text { before } \\
1940 \\
\end{array}$ & & neither & No & no & no died & $\begin{array}{l}\text { no never } \\
\text { in cty } 2\end{array}$ & add & zero & add & zero & zero & zero & zero & zero & b1d1 \\
\hline & & & & & & & & & & & & & & & & & \\
\hline
\end{tabular}




\begin{tabular}{|c|c|c|c|c|c|c|c|c|c|c|c|c|c|c|c|c|c|}
\hline \multirow[t]{2}{*}{ Variable } & \multirow[t]{2}{*}{ cty 2} & & & & \multicolumn{2}{|c|}{$\begin{array}{l}\text { In } \\
\text { population } \\
\text { in } 1930 \text { in }\end{array}$} & \multicolumn{2}{|c|}{ In population in 1940 in } & \multicolumn{2}{|c|}{ Births } & \multicolumn{2}{|c|}{ Deaths } & \multicolumn{2}{|c|}{ Inmigrant } & \multicolumn{2}{|c|}{ outmigrant } & \multirow[t]{2}{*}{ variable } \\
\hline & & & & $\begin{array}{l}\text { Where } \\
\text { in } \\
1940 \\
\end{array}$ & $\begin{array}{l}\text { cty } \\
1\end{array}$ & $\begin{array}{l}\text { cty } \\
2\end{array}$ & Cty 1 & Cty 2 & cty 1 & cty 2 & cty 1 & cty2 & cty 1 & cty 2 & ct1 & cty 2 & \\
\hline p2s2 & & $\begin{array}{l}\text { stays in } \\
\text { cty } 2 \\
\text { through } \\
1940\end{array}$ & & Cty 2 & No & yes & no & yes & zero & zero & zero & zero & zero & zero & zero & zero & $\mathrm{p} 2 \mathrm{~s} 2$ \\
\hline $\mathrm{p} 2 \mathrm{~m} 1 \mathrm{~s} 1$ & & & $\begin{array}{l}\text { stays in } \\
\text { cty } 1 \\
\text { through } \\
1940\end{array}$ & Cty 1 & No & yes & $\begin{array}{l}\text { yes } \\
\text { (inmigrant) }\end{array}$ & no & zero & zero & zero & zero & add & zero & zero & add & p2m1s1 \\
\hline $\mathrm{p} 2 \mathrm{~m} 1 \mathrm{~m} 2$ & $\begin{array}{l}\text { In cty } \\
2 \text { in } \\
1930\end{array}$ & $\begin{array}{l}\text { migrates } \\
\text { to cty } 1 \\
\text { pre } \\
1940\end{array}$ & $\begin{array}{l}\text { returns } \\
\text { to cty } 2 \\
\text { pre } \\
1940\end{array}$ & Cty 2 & No & yes & $\begin{array}{l}\text { no } \\
\text { (returned } \\
\text { to cty 2) }\end{array}$ & $\begin{array}{l}\text { Yes } \\
\text { (returned } \\
\text { to cty two }\end{array}$ & zero & zero & zero & zero & add & add & add & add & $\mathrm{p} 2 \mathrm{~m} 1 \mathrm{~m} 2$ \\
\hline $\mathrm{p} 2 \mathrm{~m} 1 \mathrm{~d} 1$ & & & $\begin{array}{l}\text { dies in } \\
\text { cty } 1 \\
\text { pre } \\
1940\end{array}$ & neither & No & yes & no died & no died & zero & zero & add & zero & add & zero & zero & add & $\mathrm{p} 2 \mathrm{~m} 1 \mathrm{~d} 1$ \\
\hline $\mathrm{p} 2 \mathrm{~d} 2$ & & $\begin{array}{l}\text { dies in } \\
\text { cty } 2 \\
\text { before } \\
1940\end{array}$ & & neither & No & yes & $\begin{array}{l}\text { never in } \\
\text { cty } 1\end{array}$ & died & zero & zero & zero & add & zero & zero & zero & zero & $\mathrm{p} 2 \mathrm{~d} 2$ \\
\hline
\end{tabular}




\begin{tabular}{|c|c|c|c|c|c|c|c|c|c|c|c|c|c|c|c|c|c|}
\hline \multirow[t]{2}{*}{ Variable } & \multirow[t]{2}{*}{ cty 2} & & & & \multicolumn{2}{|c|}{$\begin{array}{l}\text { In } \\
\text { population } \\
\text { in } 1930 \text { in }\end{array}$} & \multicolumn{2}{|c|}{ In population in 1940 in } & \multicolumn{2}{|c|}{ Births } & \multicolumn{2}{|c|}{ Deaths } & \multicolumn{2}{|c|}{ Inmigrant } & \multicolumn{2}{|c|}{ outmigrant } & \multirow[t]{2}{*}{ variable } \\
\hline & & & & $\begin{array}{l}\text { Where } \\
\text { in } \\
1940 \\
\end{array}$ & $\begin{array}{l}\text { cty } \\
1\end{array}$ & $\begin{array}{l}\text { cty } \\
2\end{array}$ & Cty 1 & Cty 2 & cty1 & cty 2 & cty1 & cty2 & cty1 & cty 2 & ct1 & cty 2 & \\
\hline b2s2 & \multirow{5}{*}{$\begin{array}{l}\text { Born } \\
\text { in cty } \\
2 \text { after } \\
1930\end{array}$} & $\begin{array}{l}\text { stays in } \\
\text { cty } 2 \\
\text { through } \\
1940 \\
\end{array}$ & & Cty 2 & No & no & never there & yes & zero & add & zero & zero & zero & zero & zero & zero & b2s2 \\
\hline b2m1s1 & & \multirow{3}{*}{$\begin{array}{l}\text { migrates } \\
\text { to cty } 1 \\
\text { pre } \\
1940\end{array}$} & $\begin{array}{l}\text { stays in } \\
\text { cty } 1 \\
\text { through } \\
1940\end{array}$ & Cty 1 & No & no & $\begin{array}{l}\text { yes } \\
\text { inmigrant }\end{array}$ & no (left) & zero & add & zero & zero & add & zero & zero & add & b2m1s1 \\
\hline $\mathrm{b} 2 \mathrm{~m} 1 \mathrm{~m} 2$ & & & $\begin{array}{l}\text { returns } \\
\text { to cty } 2 \\
\text { pre } \\
1940\end{array}$ & Cty 2 & No & no & $\begin{array}{l}\text { no } \\
\text { (returned } \\
\text { to 2) }\end{array}$ & $\begin{array}{l}\text { yes } \\
\text { (returned } \\
\text { after } \\
\text { migrating) }\end{array}$ & zero & add & zero & zero & add & add & add & add & $\mathrm{b} 2 \mathrm{~m} 1 \mathrm{~m} 2$ \\
\hline $\mathrm{b} 2 \mathrm{~m} 1 \mathrm{~d} 1$ & & & $\begin{array}{l}\text { dies in } \\
\text { cty } 1 \\
\text { pre } \\
1940 \\
\end{array}$ & neither & No & no & no died & $\begin{array}{l}\text { no died in } \\
\text { cty } 1\end{array}$ & zero & add & zero & add & add & zero & zero & add & $\mathrm{b} 2 \mathrm{~m} 1 \mathrm{~d} 1$ \\
\hline $\mathrm{b} 2 \mathrm{~d} 2$ & & $\begin{array}{l}\text { dies in } \\
\text { cty } 2 \\
\text { before } \\
1940\end{array}$ & & neither & No & no & never there & no died & zero & add & add & zero & zero & zero & zero & zero & $\mathrm{b} 2 \mathrm{~d} 2$ \\
\hline
\end{tabular}

